\title{
Archaeobotanical Analysis of Food and Fuel Procurement from Fulayj Fort (Oman, 5th-8th c. CE) Including the Earliest Secure Evidence for Sorghum in Eastern Arabia
}

\author{
Vladimir Dabrowski ${ }^{1}$, Charlène Bouchaud ${ }^{1}$, Margareta Tengberg ${ }^{1}$, Antoine Zazzo ${ }^{1}$, Seth Priestman ${ }^{2}$ \\ ${ }^{1}$ Archéozoologie, Archéobotanique : Sociétés, pratiques et environnements (UMR 7209), Muséum \\ national d'Histoire naturelle/CNRS, 43 rue Buffon - CP56, 75005 Paris (France). \\ vladimir.dabrowski@gmail.com (Corresponding Author) \\ charlene.bouchaud@mnhn.fr \\ margareta.tengberg-mongne@mnhn.fr \\ antoine.zazzo@mnhn.fr
}

${ }^{2}$ Department of Archaeology, Durham University, South Road, Durham DH1 3LE (UK).

seth.priestman@gmail.com

\section{Abstract}

The recent study of botanical macro remains from the Late Sasanian and Early Islamic (5th to 8th century) fort of Fulayj (Batinah, Sultanate of Oman) provides a unique opportunity to discuss food and fuel acquisition strategies in an arid environment and to document periods that are little known from an archaeobotanical perspective in Eastern Arabia. Seed assemblages include the first wellidentified and directly radiocarbon dated evidence of sorghum (Sorghum bicolor ssp. bicolor (L.) Moench.) in Eastern Arabia, which raises the question of whether the grain was imported from distant sources (for example Yemen, East Africa or India) or locally cultivated. In addition to sorghum, the food plant assemblage includes hulled barley (Hordeum vulgare), date (Phoenix dactylifera) and jujube (Ziziphus cf. spina-christi). Date palm gardens may have existed near to the site as they do today or food products may have been brought from date palm gardens on the Batinah coast where conditions for agricultural production are particularly favourable. Charcoal analysis reveals that the main taxa used for fuel (acacia, prosopis, jujube tree, tamarisk) were collected from local plant communities, occasionally supplemented with firewood gathered in the foothills and mountainous areas.

Key-words: Archaeobotany; Eastern Arabia; Sasanian and Early Islamic periods; Sorghum; Oasis agriculture; Fuel management. 


\section{Introduction}

Direct archaeological evidence concerning agricultural practices and fuel collection strategies during the Sasanian and Islamic periods in Eastern Arabia remain very rare. The archaeobotanical study conducted at the Sasanian and Islamic period site of Kush (Ra's al-Khaimah, UAE) represents the first study of its kind within the region but has been only partially published (Kennet 2009, 1997, Tengberg 2005). Publication of the whole corpus remains in progress (Dabrowski 2019: 159-200; Dabrowski et al. forthcoming; Tengberg et al. forthcoming). Recent archaeological investigations conducted at the Late Sasanian and Early Islamic fort of Fulayj on the Batinah plain (Sultanate of Oman), occupied from the c. early 5th to 8th century, provides a significant opportunity to increase our knowledge of the plant economy by studying macro-botanical remains (seeds, fruits, charcoals) from the only known site of this date in Oman (Priestman 2019, al-Jahwari et al. 2018). This study sheds light on food and fuel acquisition strategies in an arid environment during the Late Sasanian and Early Islamic periods. Moreover, it offers the earliest secure identification of sorghum in Eastern Arabia and allows us to raise the question of whether it was an imported commodity or incorporated into local oasis agriculture during this period. Of particular importance is the opportunity to securely document the process of diffusion by obtaining evidence for where the crop is attested for the first time. To properly assess its age, an additional date has been obtained directly from the available sorghum remains. The integration of sorghum into the general plant supply system is an issue of particular interest.

Sorghum (Sorghum bicolor ssp. bicolor) is a drought-resistant and warmth-loving crop, frequently cultivated today in agrarian systems of the tropical and sub-tropical regions of the Old World (Africa, South Asia). It is used for human consumption (eaten as grilled and boiled grains, transformed into a flour for porridge, or fermented for alcoholic beverages). It is also frequently used as fodder for livestock (Chantereau et al. 2013, Stenhouse and Tippayaruk 1996). Sorghum is a crop of African origin with its wild complex ancestor, S. bicolor ssp. verticilliflorum Steud. (Stapf.). The earliest evidence of cultivated sorghum undergoing domestication comes from contexts dated to the mid- to late 4th millennium BCE in eastern Sudan as indicated by sherd impressions of grains, spikelets and chaff (Barron et al. 2020, Winchell et al. 2017). Archaeobotanical investigations reveal the continuity of sorghum cultivation during the following millennia in Eastern Africa (Beldados 2019, Fuller and Stevens 2018, Fuller 2014, Walshaw 2010, Clapham and Rowley-Conwy 2007, Van der Veen and Lawrence 1991). The crop was introduced into the Indian sub-continent during the 2nd millennium BCE (Winchell et al. 2018, Fuller and Boivin 2009, Fuller 2003), where it was considered a marginal crop. Its importance in South Asia seems to have increased from the turn of the Christian era and in particular from the 8th century CE although archaeobotanical data is still generally lacking (Boivin et al. 2014). Genetic and archaeobotanical evidence allows us to document the evolution of this crop and its varietal differentiation during its diffusion in Africa and Asia. According to these researches, five main complexes of landraces have been defined. The original "bicolor" is characterised by hulled grains while the four others have evolved in the form of free-threshing and larger-grained specimens. "Caudatum" appeared in the Sahelian region, "durra" is probably originated from the Indian subcontinent and "guinea" from western Africa. The latter provides the origin of race "kafir" in southern Africa by the intermediate development of one more forest adapted "mageritiferum" type (Smith et al. 2019, Fuller and Stevens 2018).

The precise date of the introduction of sorghum into the Arabian Peninsula is not well known (see below). The earliest reported date of sorghum in the region is from the 3rd millennium $B C E$ occupation of Hili 8 (Abu Dhabi, UAE) in the form of carbonised grains and mudbrick impressions (Cleuziou 1982, Cleuziou and Costantini 1982). However, several researchers have questioned this early discovery due to morphological considerations of the published material consisting mainly of 
photographs of plant impressions on mudbrick (Bouchaud et al. 2016, Tengberg 2012, Charbonnier 2008, de Moulins et al. 2003). In addition, caryopses (grains) and starch grains have been potentially identified at the site of Khor Rori/Sumhuram (Dhofar, Sultanate of Oman), occupied from the 2nd century $\mathrm{BCE}$ to the 5th century $\mathrm{CE}$, but their state of preservation does not allow a secure identification (Bellini et al. 2020). The single other well-documented occurrence comes from the Islamic period coastal settlement of Qalhât in Oman (14th to 16th century) (Dabrowski et al. 2015).

\section{Environmental and historical background}

\subsection{The Batinah plain and the al-Hajar mountains}

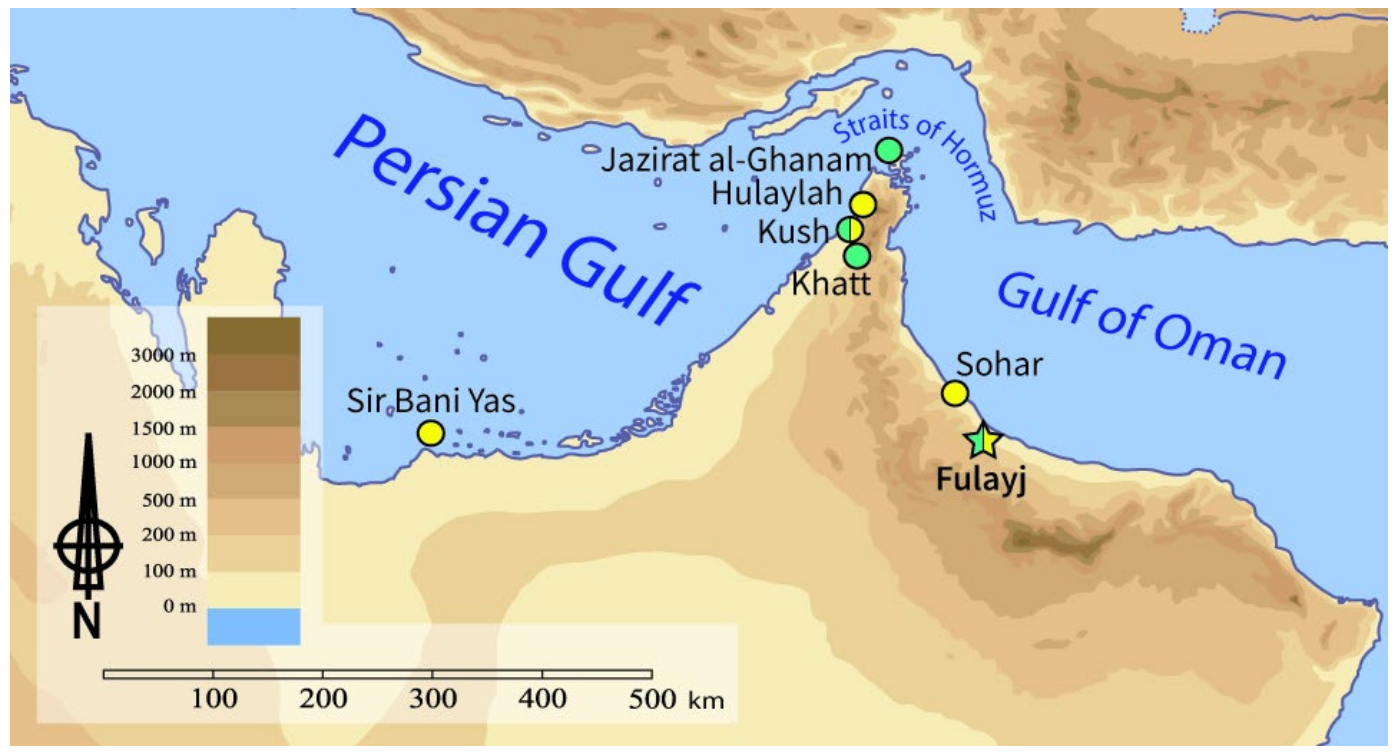

Figure 1: Location of Fulayj fort and other contemporaneous sites in Southeast Arabia. Blue = sites occupied during the Late Sasanian period (5th-6th century), yellow = those which belong to the Early Islamic period (7th8th century) (This figure should be in colour)

Wadis flowing from the mountains bring fine clayey loam onto the Batinah plain where they are deposited in a 2-5 km wide band. This phenomenon, known as khabra, as well as the presence of a higher water table in the foothill area, account for the high agrarian potential of the region (Sanlaville 2000: 140-141). A large continuous band of date palm gardens irrigated by runoff water and from wells stretch along the coastline of the Batinah. Date palms plunge their roots directly into the brackish water of the groundwater table. Other crops are cultivated in gardens 2-3 km behind the line of the palm trees protecting them from salty winds from the sea (Wilkinson 1977: 48-49). Today 
The vegetation cover of the Batinah plain has been heavily impacted by human activities. In particular, over-grazing by domestic herds prevents the regeneration of many fragile plant species (Ghazanfar 1998a). The velvet mesquite (Prosopis juliflora), an invasive species from Central and South America, has also been reported from the plain where it threatens the indigenous biodiversity (al-Abdali 2019 et al., Ghazanfar 1996). The flora belongs predominantly to the Nubo-Sindian phytogeographical region, characterised by dry sub-tropical plant communities (Ghazanfar 1992). Open thorn woodlands (Figure 2) are composed of Acacia ehrenbergiana, A. tortilis, Prosopis cineraria and Ziziphus spina-christi, associated with shrubs such as Lycium shawii and Ochradenus arabicus. Among the annual plant species can be mentioned Zygophyllum simplex, Plantago ovata, Aizoon canariense and Cometes surratenis (Ghazanfar 1998b). Some species growing mainly in the foothills and in the lower parts of the mountains such as Rhazya stricta, Fagonia indica and Maerua crassifolia also occur on the plain (Ghazanfar 2003: 2).

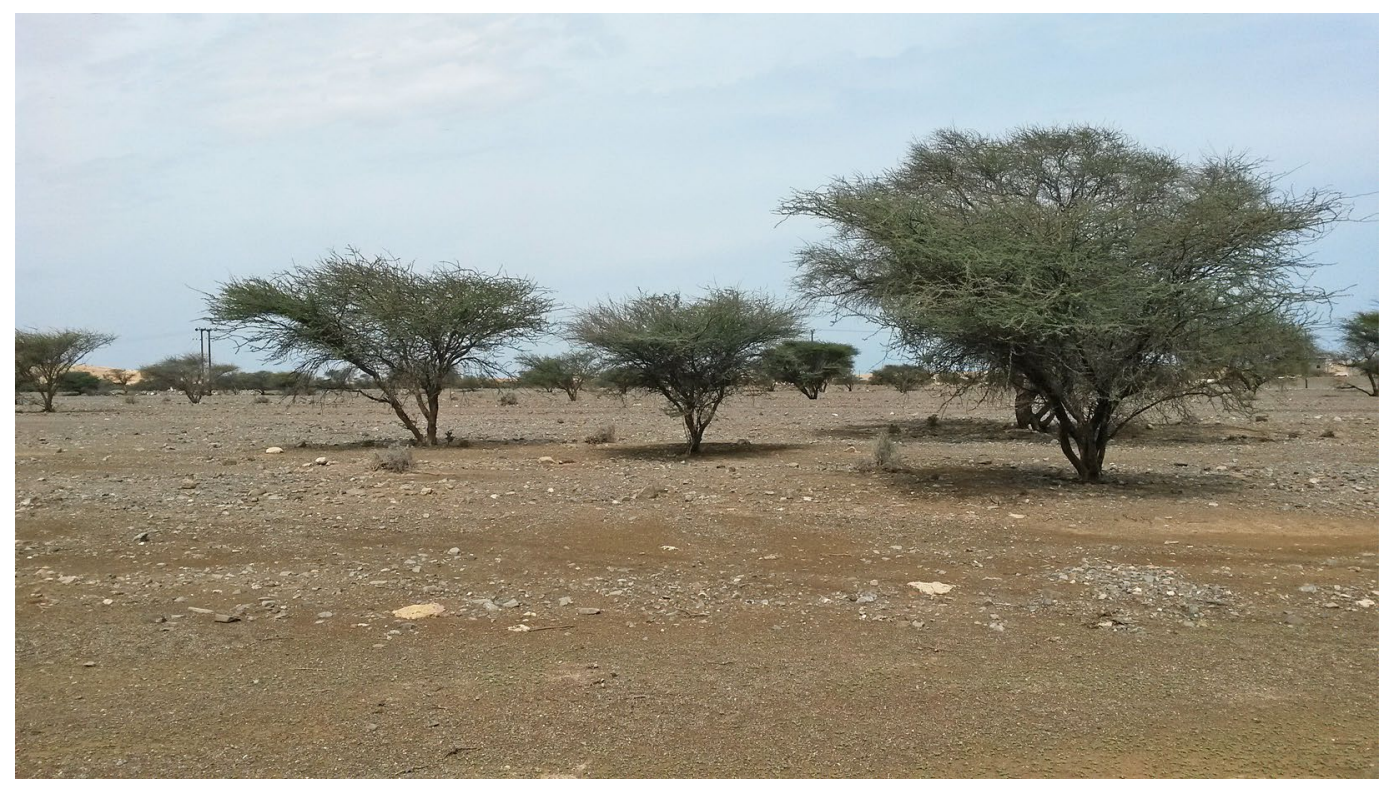

Figure 2: Today's vegetation cover of the Batinah plain. We can see here an open thorny woodland composed mainly of acacia (Acacia tortilis (Forssk.) Hayne) (This figure should be in colour)

The vegetation of the northern al-Hajar mountains, situated at a distance of about 10-15 kilometres from the site, is composed of different types of vegetation communities structured according to altitude and hydrological conditions. Between 650 and 1000 m, Acacia-Rhazya-Fagonia formations are, like in the Batinah Plain, heavily impacted by over-grazing leaving non-palatable, toxic species such as Rhazya stricta and Fagonia indica as dominant elements. Some characteristic species of seasonally flooded wadis such as Ficus cordata ssp. salicifolia and Tephrosia apollinea are also recorded. The vegetation cover between 1000 and $1500 \mathrm{~m}$ is dominated by Euphorbia larica shrub associated with acacias (A. tortilis, A. gerardii) and Periploca aphylla (Deil al-Gifri 1998). Higher slopes (c. 1100-2500 m) are dominated by formations with Olea europaea, Sideroxylon mascatense and Dodonaea viscosa associated with xeric shrub species such as Grewia erythraea, Barleria candida and succulents such as Caralluma aucheriana. Finally, the highest zone, situated between 2100 and 3000 $\mathrm{m}$, is characterised by Juniperus-Ephedra-Teucrium vegetation-type (Ghazanfar 2003: 2, Ghazanfar 
1991). Several of the mountainous formations cited above are also heavily impacted by over-grazing practices which deeply degrade the vegetation cover (Brinkmann et al. 2009).

\subsection{The Sasanian and Early Islamic period}

The extent of Sasanian influence in Eastern Arabia is a subject that has been much debate among historians and archaeologists. Although Sasanian authorities from Persia appear to have shown interest in Eastern Arabia since the military conquest of Ardashir I, around 240 CE (Potts 1990: 232234), the nature of this involvement remains difficult to determine precisely. During the Late Sasanian period, from the reign of Khusraw I (531-579 CE), Sasanian influence in Oman is more firmly attested (al-Tabarī in Bosworth 1999: 237; 253, Potts 1990: 249; 335) but the nature and degree of the occupation are still not clearly defined. Some historians propose that the Sasanian occupation of the Oman Peninsula was extensive on the Batinah plain and that the establishment of numerous afläj (underground water systems) and the settlement of Persian soldiers as landowners indicate a substantial agrarian development. Military fortresses and quarters for garrisons are also thought to have been built in the region (respectively Rustaq, Sohar) (Wilkinson 2010: 57-60, Wilkinson 1979: 888-889, Wilkinson 1977: 130-133). Economic interest has also been advanced to explain the high degree of involvement of the Sasanians in Eastern Arabia either to secure maritime exchange routes within the Persian Gulf and the wider Indian Ocean (Yemen, India) (Daryaee 2003) or the supply of copper in response to the Roman interdiction to export it to the Sasanian Empire (Morony 20012002).

However, other historians have adopted a more critical approach to the Persian and Arabic chronicles written several centuries after the events upon which they report. They suggest that this economic development during the Late Sasanian period in Eastern Arabia may not have been as important as originally thought (Munt 2017, Ulrich 2011). Archaeological research tends to supports this hypothesis. A reassessment of Sasanian archaeological data in Eastern Arabia (Kennet 2007) suggests a decline of settlement and economic indices compare to the previous period, although more data are needed in order to further validate this point. In general, archaeological discoveries securely attributed to the Sasanian period are scarce: they correspond to a few sites that are mostly limited in extent, such as Kush (Kennet 2009, 2004, 1997), Khatt (Kennet 1998) and Jazirat al-Ghanam (de Cardi et al. 1975, de Cardi 1972) as well as isolated graves and small finds (coins, seals, figurines, etc.) (Simpson 2019, Kennet 2007).

The adoption of Islam in Eastern Arabia was not only an event of spiritual importance but also one with far reaching political and economic consequences. After a first agreement between the Prophet Muhammad and the main tribes of Arabian periphery in $630 \mathrm{CE}$ allowing them to keep some privileges in exchange for their conversion to Islam and submission to the new state of Mecca, some tribes decided to rebel at the death of the Prophet in $632 \mathrm{CE}$ during the episode known as the riddah (apostasy). But the defectors were quickly defeated by the remaining loyalist groups with the help of military troops from Mecca during a battle possibly near Dabâ (Dibba). According to textual references, Persian populations which were settled in Oman during this period refused to convert to Islam and were therefore targeted by Arab converts and defeated before leaving the area (Moez 2007). Shortly after, the region of Oman declared its independence from the central Caliphate between 656 and $692 \mathrm{CE}$. After several reconquest attempts, the independent state was eventually defeated by the Umayyads between 694 and 705 CE before a period of relative peace and prosperity ensued lasting until $750 \mathrm{CE}$, when the Abbasids overthrew the dynasty of the Umayyads (al-Rawas 2000: 61-67). After another attempt at establishing an independent Omani state by the Ibadis, the new dynasty took control over this region in 752 CE until the end of the 8th century (al-Rawas 2000: 111-133). 
Very few archaeological sites are securely attested dating to the initial period of conversion to Islam in Eastern Arabia. In addition to Kush, where the occupation continues until the 13th century, the extensive but short-lived settlement of Jazirat al-Hulaylah (Ra's al-Khaimah, UAE) and the harbour of Sohar (Sultanate of Oman) in the Gulf of Oman show clear evidence of occupation during the 7th and 8th centuries (Kennet 2012, 2009, 2007). Some Christian settlements (churches, monasteries) such as Sir Bani Yas (Abu Dhabi, UAE) are also attested from this period, though their distribution appears to be restricted to the area of the Gulf (Simpson 2019; Carter 2008).

The recent discovery of the Late Sasanian fort of Fulayj on the Batinah plain (Sultanate of Oman), occupied between the early 5th to 8th century, provides unique information about the nature of the Sasanian occupation. Moreover, with the exception of the tower from the site of Kush, this is the only site in Eastern Arabia to document the transition between the end of Antiquity and the beginning of the Islamic period (al-Jahwari et al. 2018). The sequence from Fulayj provides information on a period which is still poorly understood archaeologically, including archaeobotanical data framed by a robust absolute chronology.

\subsection{The archaeological site of Fulayj}

The archaeological site of Fulayj (FJ3.S3) corresponds to a complex dated mainly to the Iron Age (1300-300 BCE) among which a Late Sasanian fort has also been identified in the north-western part. The fort of Fulayj (Figures $\mathbf{3}$ and $\mathbf{4}$ ) is 30 meters square with neatly constructed stone walls measuring on average $2.66 \mathrm{~m}$ thick with projecting ' $U$ ' shaped corner towers, a narrow $1.62 \mathrm{~m}$ wide entrance in the east, and entrance flanking towers. It is likely that the stone base supporting a mudbrick superstructure coated with lime mortar. The construction and the planning of the fort suggest a high degree of experience, proficiency and planning consistent with the interpretation of the site being built by an external military force. Several trenches were opened during the excavation seasons in 2015 and 2016: some within the interior (Trenches A, F, G) and some outside (Trenches B, $\mathrm{N}$ ) the fort as well as on both sides of the main gateway and entrance flanking towers (Trench $E$ ). To the south of the fort, several lime kilns probably used during the construction of the fort have been detected; a single test pit was excavated in this area (Trench C). Pottery sherds, small finds and a set of 25 radiocarbon dates obtained from selected carbonized macro-botanical remains have permitted the dating of several phases of occupation. Some Iron Age levels (1000-500 BCE, Phase 1) have been excavated below the level of the fort. The construction and first occupation of the fort are dated to the Late Sasanian period (between the early 5th to mid-6th century, Phase 2). Another occupation, either continuous or after an abandonment, has been assigned to the Early Islamic period (late 6th to 8th century, Phase 3). This phase is associated with the secondary insertion of mudbrick architecture inside the fort in Trench $\mathrm{F}$ and the later construction of an oven, possibly indicating a shift in site function from a military to a domestic occupation. After the general abandonment of the fort, some irregular walls and later pottery indicate limited activity within the area dated to the Late Islamic Period (16th to 20th century, Phase 4) (al-Jahwari et al. 2018). Phases 1 and 4 have been mainly excluded from the archaeobotanical study because they are not directly linked to the occupation of the fort. 


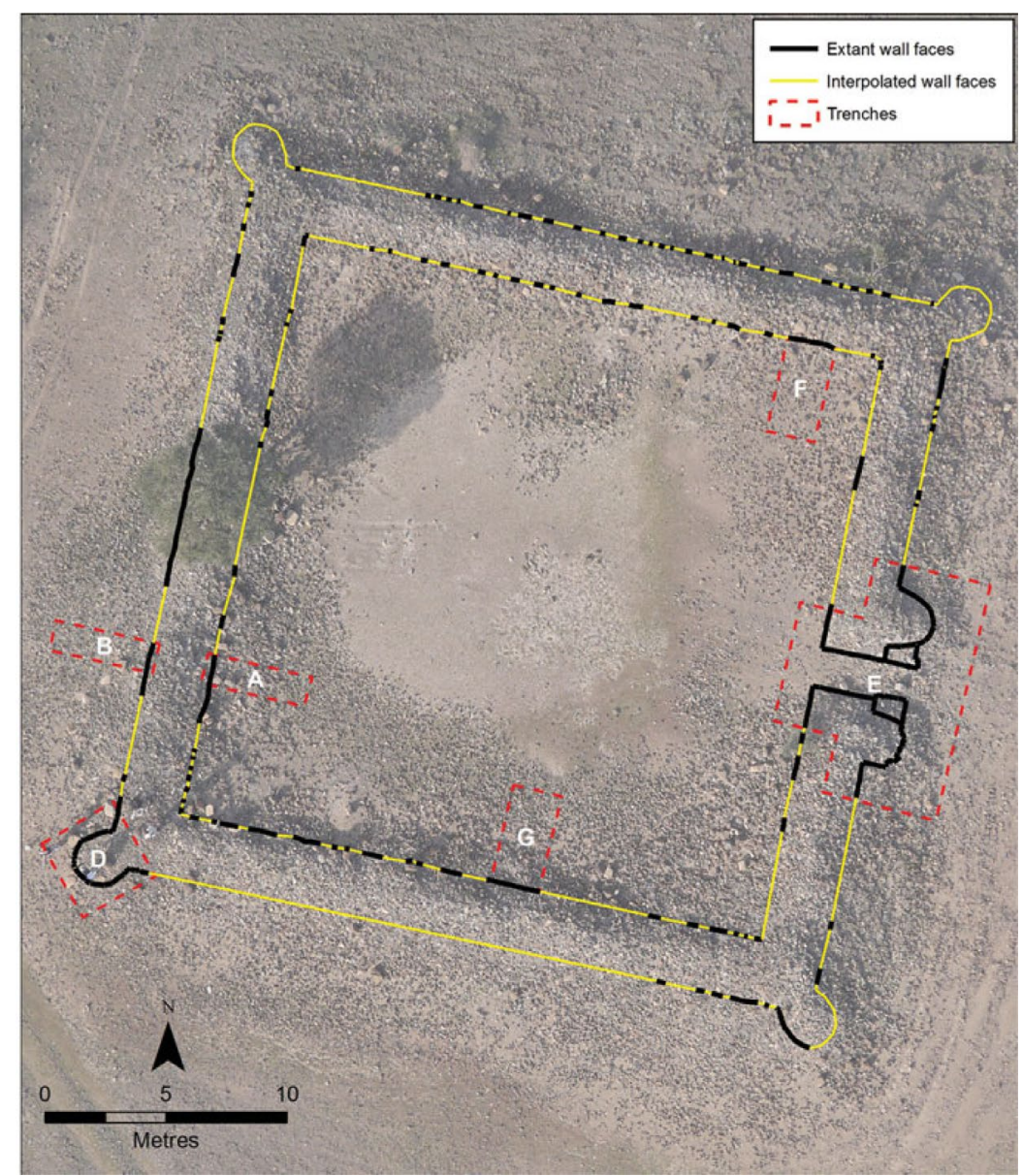

Figure 3: Aerian view of the Fulayj fort with trenches opened during the two field campaigns in 2015 and 2016 (C) Fulayj Project) (This figure should be in colour)
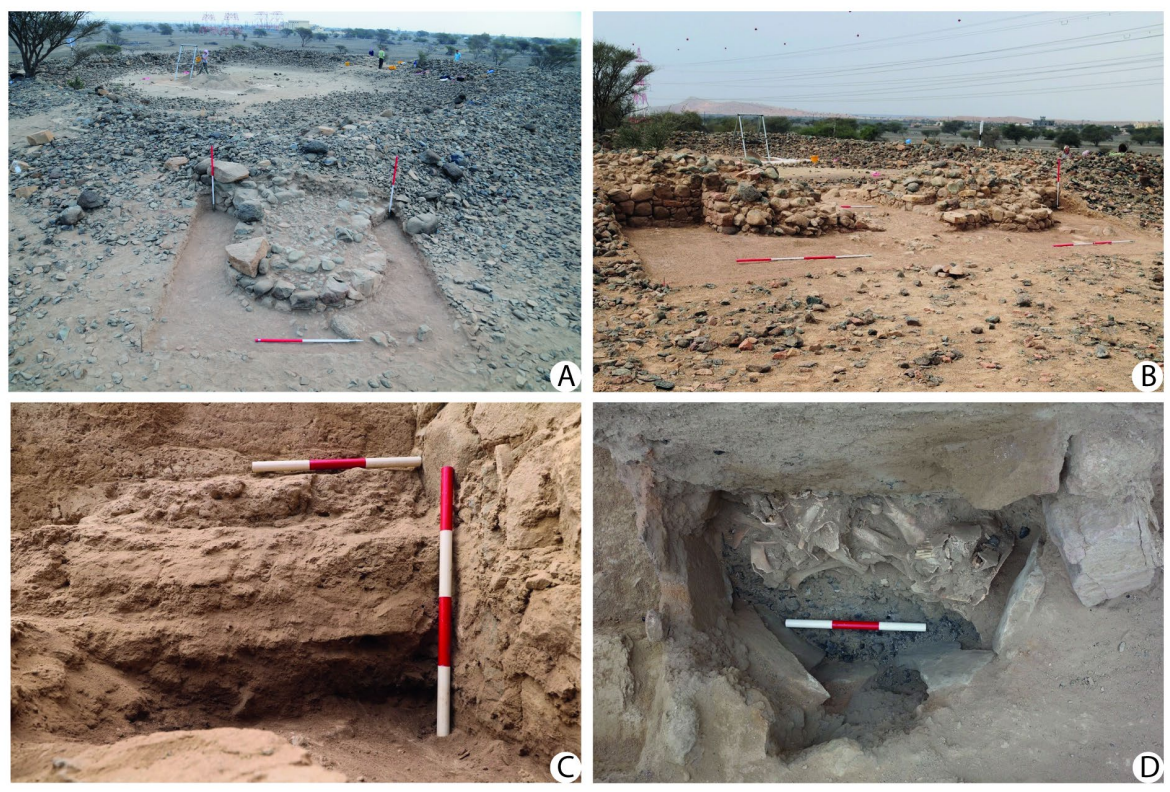

Figure 4: Details of the Fulayj fort. A: The south-west projecting corner tower of the fort; B: The fort entranceway looking north-west with entrance-flanking towers; C: Mudbrick wall (F.021) of Phase 3 in Trench F; D: Fill of the oven consisting of a dense accumulation of animal bone within the upper layer (F.026) and charcoal concentrated towards the base (F.047) (C Fulayj Project) (This figure should be in colour). 
The size of the building, the thickness and regularity of the walls and the presence of towers highlight its military and defensive functions. Thus, it constitutes one of a very limited number of attested military constructions dated to the Late Sasanian period in Eastern Arabia, and the only one facing the Indian Ocean within the main portion of Oman. Other potentially military structures include the tower from the site of Kush whose structure and function are not precisely determined and the 'watch station' from Jazirat al-Ghanam in Northern Oman, which although seemingly contemporary to Fulayj, lacks substantial defensive capabilities. The scarcity of domestic remains like pottery sherds (only 346 for phases 2 and 3 ) and animal bones within the building at Fulayj seems to further support the interpretation of a military function. Those pottery finds that do occur mostly originate from southern Mesopotamia and Iran, then under Sasanian domination, suggesting that foreign soldiers may have been provisioned directly from outside by the Sasanian state. Indian pottery has also been found and appears to indicate a degree of integration into long-distance exchange networks within the western Indian Ocean (al-Jahwari et al. 2018). This fort may have been part of a wider defensive network (Kennet et al. 2016) devoted to securing the fertile sectors and supply routes of the Batinah plain while maintaining strategic control of the coastal territory. These archaeological discoveries may be in position to comfort textual data about defensive strategy of the Sasanian Empire conducted by Khusraw I during the 6th century CE (al-Jahwari et al. 2018).

\section{Material and Methods}

\subsection{Macro-botanical remains}

Botanical macro-remains were collected from 41 contexts (occupation levels, dump deposits, pits, foundation trenches, hearths, ovens, mudbrick collapses, water- and wind-blown deposits) excavated in Trenches A, B, E, F, G and N (Table 1). Most samples come from Trench $F(N=13)$ while other trenches have provided from 3 (Trench $N$ ) to 8 sediment samples (Trench $A)$. The Early Islamic period is most well represented $(N=15)$, followed by the Late Islamic period $(N=12)$, the Iron age $(N=7)$ and the Late Sasanian period $(\mathrm{N}=7)$. We aimed at collecting at least 10 litres of sediment whenever possible but according to the context. Sample volumes range from less than 1 litre to 25 litres. In total, 592.5 litres of sediment have been processed at the archaeological base in Sohar during fieldwork in March 2016. Manual bucket flotation in which plant remains were recovered on a 0.3 $\mathrm{mm}$ mesh sieve was used for all of the samples except for the concentration of large-size charcoal pieces from an oven (F.047). This assemblage was sub-sampled before being dry-sieved with a $2 \mathrm{~mm}$ mesh and the fine fraction (less than $2 \mathrm{~mm}$ ) floated. All processed samples were analysed at the National Museum of Natural History in Paris (France).

\begin{tabular}{|c|c|c|c|c|c|c|c|}
\hline Season & Trench & Context & Phase & Nature and Description & $\begin{array}{c}\text { Volume } \\
\text { (litres) }\end{array}$ & $\begin{array}{l}\text { Seed/fruit } \\
\text { analysis }\end{array}$ & $\begin{array}{l}\text { Charcoal } \\
\text { analysis }\end{array}$ \\
\hline 2015 & $A$ & A.005 & 4 & Wind-blown deposit & 11 & + & \\
\hline 2015 & $A$ & A.006 & 4 & Wind-blown deposit & 18 & + & \\
\hline 2015 & $A$ & A.009 & 4 & Wind-blown deposit & 16 & + & \\
\hline 2015 & $A$ & A.013 & 2 & Occupation layer & 15 & + & \\
\hline 2015 & $A$ & A.014 & 3 & Hearth & 20 & + & + \\
\hline 2015 & $A$ & A.016 & 3 & Soft occupation deposit & 18 & + & + \\
\hline 2015 & $A$ & A.018 & 2 & Occupation layer & 19 & + & \\
\hline 2015 & $A$ & A.019 & 2 & Surface layer & 15 & + & \\
\hline 2015 & B & B.003 & 4 & Wind-blown deposit & 19 & + & \\
\hline 2015 & $B$ & B.004 & 4 & Water-flooded deposit & 23 & + & \\
\hline 2015 & $B$ & B.006 & 4 & Wind-blown deposit & 22 & + & \\
\hline 2015 & $B$ & B.007 & 2 & Occupation deposit & 22 & & + \\
\hline 2015 & B & B.008 & 1 & Occupation layer & 20 & + & \\
\hline
\end{tabular}




\begin{tabular}{|c|c|c|c|c|c|c|c|}
\hline Season & Trench & Context & Phase & Nature and Description & $\begin{array}{l}\text { Volume } \\
\text { (litres) }\end{array}$ & $\begin{array}{l}\text { Seed/fruit } \\
\text { analysis }\end{array}$ & $\begin{array}{l}\text { Charcoal } \\
\text { analysis }\end{array}$ \\
\hline 2015 & $B$ & B.009 & 2 & Foundation trench fill & 25 & + & \\
\hline 2016 & $E$ & E.020 & 3 & Occupation deposit & 11 & + & \\
\hline 2016 & $E$ & E.022 & 3 & Occupation deposit & 10 & + & \\
\hline 2016 & $E$ & E.024 & 3 & Occupation deposit & 11 & + & \\
\hline 2016 & $E$ & E.027 & 2 & Surface layer & 9.5 & + & \\
\hline 2016 & $E$ & E.028 & 2 & Surface layer & 8 & + & \\
\hline 2016 & $\mathrm{~F}$ & F.009 & 4 & Edge of a fire pit & $<1$ & + & \\
\hline 2016 & $\mathrm{~F}$ & F.010 & 4 & Edge of a fire pit & 9 & + & \\
\hline 2016 & $\mathrm{~F}$ & F.011 & 4 & $\begin{array}{l}\text { Windblown deposit with mudbrick } \\
\text { decay }\end{array}$ & 10 & + & \\
\hline 2016 & $\mathrm{~F}$ & F.015 & 2 & Mudbrick decay with burning & 20 & + & \\
\hline 2016 & $\mathrm{~F}$ & F.017 & 3 & Mudbrick decay & 8 & + & \\
\hline 2016 & $\mathrm{~F}$ & F.019 & 2 & Occupation layer & 19 & + & \\
\hline 2016 & $\mathrm{~F}$ & F.026 & 3 & $\begin{array}{l}\text { Upper fill of the oven consisting } \\
\text { mostly of animal bone }\end{array}$ & 20 & + & + \\
\hline 2016 & $\mathrm{~F}$ & F.027 & 3 & Windblown deposit above the oven & 9 & + & \\
\hline 2016 & $\mathrm{~F}$ & F.030 & 2 & Occupation layer & 3 & + & + \\
\hline 2016 & $\mathrm{~F}$ & F.035 & 3 & Occupation layer & 20 & + & \\
\hline 2016 & $\mathrm{~F}$ & F.036 & 2 & Fill of post-hole & 10 & + & \\
\hline 2016 & $\mathrm{~F}$ & F.045 & 2 & Occupation layer & 18 & + & \\
\hline 2016 & $\mathrm{~F}$ & F.047 & 3 & $\begin{array}{l}\text { Lower fill of the oven consisting of } \\
\text { charcoal and ash }\end{array}$ & 11 & + & + \\
\hline 2016 & G & G.006 & 4 & Occupation deposit & 10.5 & + & \\
\hline 2016 & G & G.008 & 3 & Occupation deposit & 10 & + & \\
\hline 2016 & G & G.010 & 1 & Occupation deposit & 20 & + & \\
\hline 2016 & G & G.014 & 1 & Hearth deposit & 10 & + & + \\
\hline 2016 & $\mathrm{G}$ & G.015 & 2 & Hearth deposit? & 3.5 & + & \\
\hline 2016 & G & G.017 & 1 & Occupation deposit & 20 & + & \\
\hline 2016 & $\mathrm{~N}$ & N.002 & 1 & Occupation deposit & 10 & + & \\
\hline 2016 & $\mathrm{~N}$ & N.005 & 1 & Occupation deposit & 22.5 & + & \\
\hline 2016 & $\mathrm{~N}$ & N.008 & 1 & Occupation deposit & 20.5 & + & \\
\hline
\end{tabular}

Table 1: List of archaeobotanical samples from Fulayj.

Macro-botanical remains were extracted from the flotation residues with the help of a binocular stereomicroscope (Nikon SMZ645). The botanical identification of seeds and fruits was based on morphological and anatomical criteria and involved the comparison of the archaeological material with modern reference collections and illustrations in seed atlases (Cappers et al. 2012, Cappers et al. 2009, Cappers et al. 2006, Jacomet 2006). All samples contained seeds and fruit remains except one (B.007). The results are expressed as Number of Remains (NR) and Minimum Number of Individuals (MNI). The MNI was determined by counting the whole remains and adding the estimation of whole individuals made from the fragments available by reconstruction to the nakedeye. Percentages were calculated with the MNI including determined and undetermined remains. The density of remains per litre was defined by dividing the total number of remains by the volume expressed in litres. Ubiquity represents the number of samples in which taxa are attested. Because they were not botanical remains stricto sensu, coprolites were not included in the calculations. However, they were also considered and will be described where relevant.

The botanical identification of charred wood fragments is based on the observation of the cellular structure (or anatomy) of the wood under a reflected-light microscope (Olympus), with 
magnifications from $\times 50$ to $\times 800$, and according to three wood-anatomical sections (transversal, longitudinal radial and longitudinal tangential) obtained by manually fracturing the charcoal fragment. As for the seed and fruit remains, we used a reference collection of modern specimens as well as anatomical atlases of wood (Neumann et al. 2001; Pajouh and Schweingruber, 1993; Schweingruber, 1990; Fahn and Werker, 1986). For the wood charcoal analysis and interpretation, a minimum number of fragments from each archaeological context is required (Chabal 1997). At Fulayj most of the samples did not contain enough charcoal fragments to be considered statistically representative and thus we chose to focus on five samples where the number of charred wood fragments was greater than 50 , a number that can be considered as sufficient in an arid environment where the diversity of tree and shrub species is relatively low. For each sample, after the discovery of a new taxon, 50 more pieces of charcoal were identified. In order to compare the taxonomical diversity between these richer samples with samples containing fewer charcoal fragments, we included two smaller samples (A.016 and B.007) in our study. In total, seven samples were processed for the charcoal study: one coming from an Iron Age hearth (G.014), one from a Late Sasanian deposit (B.007) and five dated to the Early Islamic period. Among the latter, one came from an occupation level (F.030), one from a rubbish deposit (A.016), one from a hearth (A.014) and two from an oven (F.026 and F.047). Four selected contexts for charcoal analysis correspond to hearths and ovens; structures with high charcoal concentrations, which are not considered suitable for quantitative analysis of past vegetation reconstitution (Chabal et al. 1999: 62-63). Therefore, the ecological interpretation will be mainly based on qualitative considerations.

\subsection{Radiocarbon dating}

One sample of sorghum (one fragmentary caryopsis of sorghum (Sorghum bicolor ssp. bicolor) and one of tamarisk twig (Tamarix sp.) from the same context (E.024) were sampled for AMS dating. The latter sample was obtained together with 24 other high-precision AMS dates provided from selected carbonized botanical remains from across the excavations used to define the site chronology. Those from Trenches A, B and C were selected by I. Van Bergen Poole (2015) while the remainder from Trenches E, F, G and N were identified by the first author of the present paper. Another date made directly on sorghum was obtained in order to establish its age in relation to the context of its recovery. Indeed, later occupation dated to the Late Islamic period (16th-20th century) has been observed within the uppermost deposits (Phase 4), and the hypothesis of contamination, although unlikely, could not be completely ruled out. In addition, one sample of tamarisk wood has been dated from another context where sorghum is attested (F.036) as one of the other dates used to establish the chronology of the site. In this case, sorghum has not been dated directly because of the nature of the archaeological remains.

Because of its very small size $(1.6 \mathrm{mg})$ the sorghum sample was subjected to a gentle acid $(\mathrm{HCl}, 1 \mathrm{~N})$ wash at room temperature for one hour, then rinsed using milli- $Q$ water and dried overnight at $90^{\circ} \mathrm{C}$. The $1 \mathrm{mg}$-sample was combusted, providing $600 \mu \mathrm{g} C$ and graphitized using an automated AGE 3 device. Radiocarbon measurement was performed using the compact AMS ECHoMICADAS at LSCE (Saclay, France). The radiocarbon age was calibrated using the Oxcal 4.4 software and the IntCal20 atmospheric curve (Bronk Ramsey 2009; Reimer et al. 2020).

\section{Results}

\subsection{The analysis of seed and fruit remains}

Seed and fruit remains are relatively rare with a total of 434 items observed (MNI= 426) (Table 2). These elements correspond to whole and fragmented seeds and fruits as well as other vegetative parts of plants such as leaves and spines. Most of the material is preserved by carbonisation (71\%) 
caused by charring occurring during daily-life activities or accidental fire. Some of them have been preserved by mineralisation (29\%). The latter correspond to Boraginaceae nutlets. However, in such cases it can be difficult to ascertain whether they are ancient remains. Indeed, they can survive in archaeological deposits by natural mineralisation (Messager et al. 2010) without any obvious morphological difference from modern specimens which makes it impossible to ascertain their age without direct dating. As a proportion may be part of the contemporary archaeological formation, we decided to take them into consideration, though we have to bear in mind their potentially problematic nature. In any case, the abundance of seed and fruit items recovered is very low, with the average density of remains per litre comprising between 0.1 and 8.2 (Figure 5). Most of the samples (79\%) have density values of less than 1 . Samples with a density of remains per litre equal or more than 1 come from an oven (F.026, F.047), two hearths (A.014, G.014), an occupation deposit (E.024) and two levels associated with combustion structures (F.009, F.027). Two samples from the same oven (F.026, F.047) have important concentrations of possible Amaranthaceae leaves which seems to underline the use of this taxon as fuel resulting in an over-representation in the assemblage ( $29 \%$ of the total).

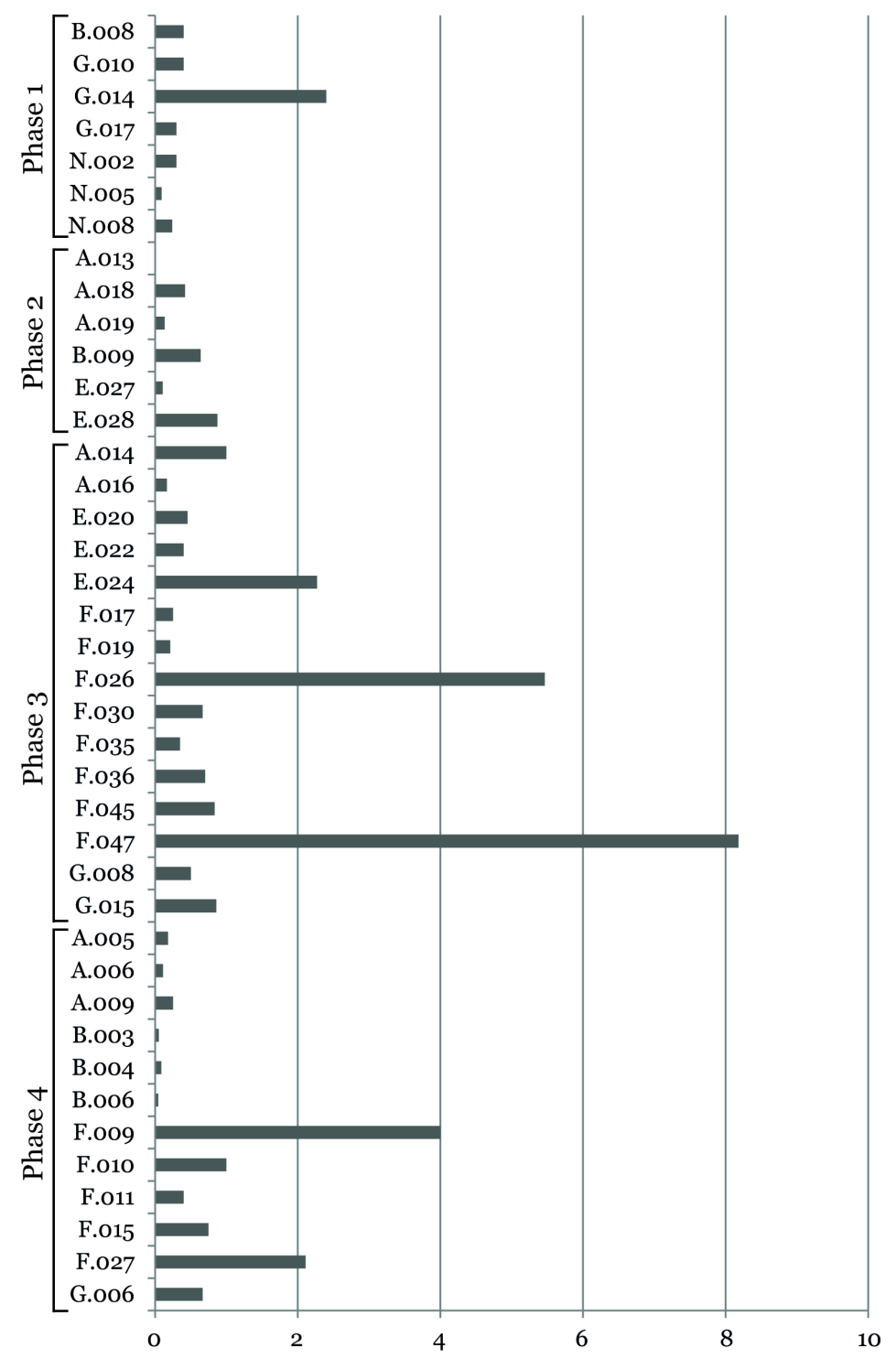

Figure 5: Density of remains per litre for all archaeobotanical samples. 
In total, the seed and fruit remains have been grouped into 27 taxa, including 8 cultivated taxa and 19 weedy/wild plants (Figure 6). Among the former, cereals and fruit trees are most frequently encountered ( $3 \%$ and $4 \%$ respectively). Among the cereals, two carbonised caryopses (grains) of sorghum (Sorghum bicolor ssp. bicolor) have been recovered from an Early Islamic context (E.024) located close to the base of the main wall outside the fort beyond the southeast entrance flanking tower. The context consists of a sandy-silt occupation deposit containing stones, animal bones, potsherds, including green coloured alkaline glazed ware (TURQ.G) and locally made coarse buff ware (COB), and two glass vessel rim fragments: one a narrow-necked bottle and the other a closed bowl. In addition, two earth impressions of sorghum grains have been found in the fill of a large posthole (F.036) within the northeast corner of the fort interior. Two fragmentary sorghum have been found in two further contexts, one dated to the Early Islamic period (A.014) and the other to the Late Islamic period (F.011), but they are not so securely identified. The sorghum grain is widely ovate to round with a shallow scutellum (embryo cavity) covering approximatively half to two-thirds of the total length of the grain (Fuller 2017). Its big size and globular aspect allow one to identify it as a domesticate specimen belonging to subspecies $S$. bicolor ssp. bicolor according to Wiersema and Dahlberg (2007).

Five main complex landraces have been defined on the basis of spikelet and inflorescence morphology and genetic features but it remains hard to differentiate them archaeologically, especially with only one whole caryopsis (Fuller and Stevens 2018). These grains constitute the first evidence of sorghum safely identified and dated in Eastern Arabia as we will see in further details below. Added to sorghum, three caryopses of hulled barley (Hordeum vulgare) are attested during Late Sasanian and Early Islamic periods, and two of free-threshing wheat (Triticum cf. aestivum/durum/turgidum) are present only in one Iron Age period hearth. It is impossible to distinguish bread hexaploid wheat (T. aestivum ssp. aestivum) from tetraploid wheats (Triticum turgidum ssp. durum/turgidum) by the sole morphology of the caryopsis. One single Panicoideae caryopsis and one potential undetermined cereal are attested respectively in a sample dated to the Early Islamic (F.047) and Late Islamic (A.009) periods. Their general state of preservation did not allow us to provide a precise identification.

Fruit trees are represented by date palm (Phoenix dactylifera) (2\%) with fragments of date seeds occurring in all occupation phases; one potential perianth (remnant parts of flowers after the fruit formation) has been recovered in one Early Islamic context (A.014). Endocarp (fruit stone) fragments of jujube (Ziziphus cf. spina christi) (2\%) have been found in samples from contexts dated to all phases, except the Late Sasanian period, and particularly during the Early Islamic period. Only one cotyledon of undetermined domesticated pulse has been found in one Late Sasanian context (E.028) but its mediocre state of preservation prevented us from obtaining a more precise identification.

Weedy/wild plant remains are more numerous than crops (70\%) with three having been identified to the species level, seven to the genus level and eight to the family or sub-family level. As these taxa are not precisely identified, it is in general difficult to determine their ecology. Their importance in the assemblage is mainly due to high proportions of Boraginaceae (29\%) nutlets and possible fragments of Amaranthaceae leave (29\%). The Amaranthaceae family includes many shrubs (formerly ascribed to the Chenopodiaceae family) often growing on saline and sandy soils in deserts, foothills and coastal areas in Northern Oman. This family is also attested by seeds from Salsola which correspond to shrubs growing mainly on sandy and rocky soils in coastal areas. The Fabaceae (4\%) and Poaceae (3\%) families are both minimally attested by several potential weeds such as barnyard grass (Echinochloa colona), foxtail (Setaria sp.), cf. Panicum sp., alfalfa (cf. Medicago sp.) and sweet clover (cf. Melilotus sp.) and other families like asphodel (Asphodelus fistulosus, Liliaceae) and 
mallow (Malva sp., Malvaceae). Barnyard grass, Setaria sp., alfalfa, sweet clover and mallow used to grow in irrigated fields (Ghazanfar 2007, 2003, 1992). These taxa are attested in the assemblage during the Early Islamic period and thus, testify agrarian practices dated to this period. Seeds of acacia/prosopis (Acacia/Prosopis) have also been identified during the Late Sasanian period. Acacia and Prosopis are two common tree taxa amongst the current vegetation cover. Their seeds could have been accidentally brought on site with wood collected as fuel or grazed by animals (Fagg and Stewart 1994).

Finally, high proportions of badly preserved and fragmented plant remains (23\%) could not be botanically determined. We can observe the presence of indeterminate remains under the form of arc that may belong to acacia/prosopis as suggested by the association with charcoals from these taxa although their nature remains to be determined. In addition, some fragments of coprolites have been noted amongst the samples. Four of them have been identified as sheep or goat pellets dated to the Early Islamic period and two of them as rodents' droppings, one to the same period and another to the Iron Age.

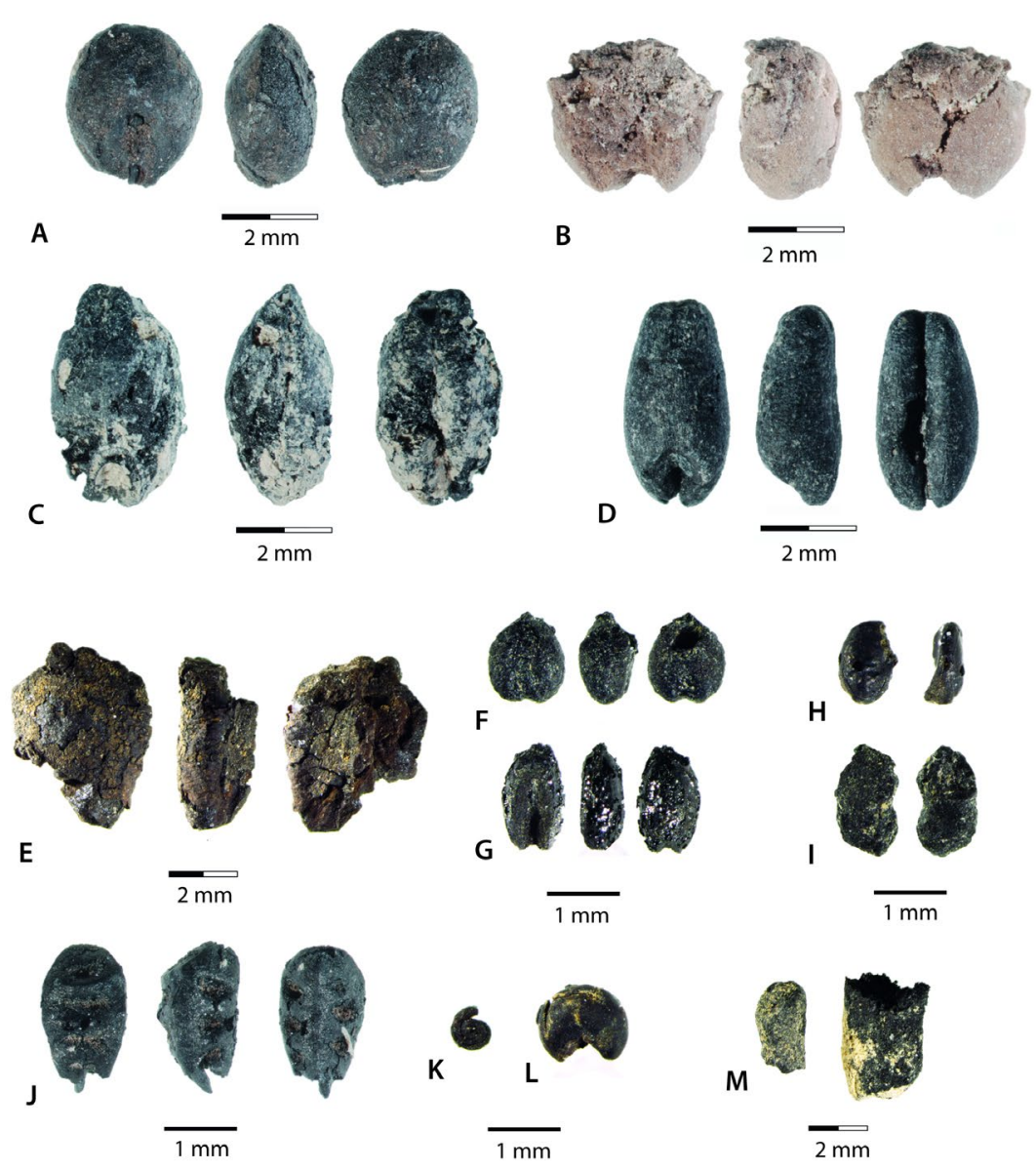

Figure 6: Seeds and fruit remains from Fulayj fort. A: Caryopsis of sorghum (Sorghum bicolor ssp. bicolor) in dorsal, lateral and ventral view; B: Earth impression of sorghum caryopsis, in dorsal, lateral and ventral view; C: Caryopsis of hulled barley (Hordeum vulgare), in dorsal, lateral and ventral view ; D: Caryopsis of free-threshing wheat (Triticum aestivum/durum/turgidum) in dorsal, lateral and ventral view; E: Fragment of date palm seed (Phoenix dactylifera) in dorsal, lateral and ventral view ; F: Caryopsis of barnyard grass (Echinochloa cf. colona) in dorsal, lateral and ventral view; F: Caryopsis of foxtail (Setaria sp.) in dorsal, lateral and ventral view; $\mathrm{H}$ : Immature seed of Acacia/Prosopis in front and lateral view ; I: Seed of wild alfalfa (cf. Medicago) on both side; J: Seed of asphodel (Asphodelus cf. tenuifolius) in dorsal, lateral and ventral view ; K: Seed of Salsola sp.; L: Seed of mallow (Malva sp.); M: Fragment of leaf (cf. Amaranthaceae).

(This figure should be in colour) 


\begin{tabular}{|c|c|c|c|c|c|c|c|c|c|c|c|c|c|c|c|c|}
\hline Period & & \multicolumn{3}{|c|}{ Phase 1} & \multicolumn{3}{|c|}{ Phase 2} & \multicolumn{3}{|c|}{ Phase 3} & \multicolumn{3}{|c|}{ Phase 4} & \multicolumn{3}{|c|}{ Total } \\
\hline Dating & & \multicolumn{3}{|c|}{ c. $1000-500$ BCE } & \multicolumn{3}{|c|}{ c. 5th-6thC CE } & \multicolumn{3}{|c|}{$\begin{array}{c}\text { c. late 6th - 8thC } \\
\text { CE }\end{array}$} & \multicolumn{3}{|c|}{ c. 16 th-20thC CE } & & & \\
\hline Trenches & & \multicolumn{3}{|c|}{$\mathrm{B}, \mathrm{G}, \mathrm{N}$} & \multicolumn{3}{|c|}{$A, B, E$} & \multicolumn{3}{|c|}{$A, E, F, G$} & \multicolumn{3}{|c|}{$A, B, F, G$} & \multicolumn{3}{|c|}{$A, B, E, F, G, N$} \\
\hline Number of samples & & \multicolumn{3}{|c|}{7} & \multicolumn{3}{|c|}{6} & \multicolumn{3}{|c|}{15} & \multicolumn{3}{|c|}{12} & \multicolumn{3}{|c|}{40} \\
\hline \multirow[t]{2}{*}{ Total of volume sieved (litre) } & & \multicolumn{3}{|c|}{123} & \multicolumn{3}{|c|}{91.5} & \multicolumn{3}{|c|}{187.5} & \multicolumn{3}{|c|}{168.5} & \multicolumn{3}{|c|}{592.5} \\
\hline & & NR & $\mathrm{MNI}$ & $U$ & NR & $\mathrm{MNI}$ & $\mathrm{U}$ & NR & $\mathrm{MNI}$ & $\mathrm{U}$ & NR & MNI & $\mathrm{U}$ & NR & $\mathrm{MNI}$ & $\%$ \\
\hline Vernacular name & Latin name & & & & & & & & & & & & & & & \\
\hline Cereals & & & & & & & & & & & & & & & & \\
\hline Hulled barley, caryopsis & Hordeum vulgare & - & - & - & 1 & 1 & 1 & 1 & 1 & 2 & - & - & - & 2 & 2 & $<1$ \\
\hline Hulled barley, fg. caryopsis & & - & - & - & - & - & - & 2 & 1 & & - & - & - & 2 & 1 & $<1$ \\
\hline Probable millet, caryopsis & cf. Panicoïdae & - & - & - & - & - & - & 1 & 1 & 1 & - & - & - & 1 & 1 & $<1$ \\
\hline Sorghum, caryopsis & Sorghum bicolor ssp. bicolor & - & - & - & - & - & - & 1 & 1 & 3 & - & - & - & 1 & 1 & $<1$ \\
\hline Sorghum, fg. caryopsis & & - & - & - & - & - & - & 1 & 1 & - & - & - & - & 1 & 1 & $<1$ \\
\hline Sorghum, earth imprint & & - & - & - & - & - & - & 2 & 2 & - & - & - & - & 2 & 2 & $<1$ \\
\hline Probable sorghum, caryopsis & cf. Sorghum bicolor ssp. bicolor & - & - & - & - & - & - & 1 & 1 & - & 1 & 1 & 1 & 2 & 2 & $<1$ \\
\hline Free-threshing wheat, caryopsis & Triticum aestivum/durum/turgidum & 2 & 2 & 1 & - & - & - & - & - & - & - & - & - & 2 & 2 & $<1$ \\
\hline Und. cereal, fg. caryopsis & Cerealia & - & - & - & - & - & - & - & - & - & 1 & 1 & 1 & 1 & 1 & $<1$ \\
\hline Pulses & & & & & & & & & & & & & & & & \\
\hline Und. pulse, cotyledon & Fabaceae & - & - & - & 1 & 1 & 1 & - & - & - & - & - & - & 1 & 1 & $<1$ \\
\hline Fruit trees & & & & & & & & & & & & & & & & \\
\hline Date, fg. seed & Phoenix dactylifera & 1 & 1 & 1 & 1 & 1 & 1 & 1 & 1 & 5 & 1 & 1 & 2 & 4 & 4 & 1 \\
\hline Probable date, fg. seed & cf. Phoenix dactylifera & - & - & - & - & - & - & 6 & 3 & - & 4 & 2 & - & 10 & 5 & 1 \\
\hline Probable date, perianthe & & - & - & - & - & - & - & 1 & 1 & - & - & - & - & 1 & 1 & $<1$ \\
\hline Jujube, fg. of endocarp & Ziziphus cf. spina-christi & - & - & - & - & - & - & 1 & 1 & 5 & - & - & - & 1 & 1 & $<1$ \\
\hline Probable jujube, fg. of endoarp & cf. Ziziphus sp. & 1 & 1 & 1 & - & - & - & 5 & 5 & - & 1 & 1 & 1 & 7 & 7 & 2 \\
\hline Weedy/Wild plants & & & & & & & & & & & & & & & & \\
\hline Acacia/Prosopis, immature seed & Acacia/Prosopis & - & - & - & 1 & 1 & 2 & - & - & - & - & - & - & 1 & 1 & $<1$ \\
\hline Probable acacia/prosopis, fg. of seed & cf. Acacia/Prosopis & - & - & - & 1 & 1 & - & - & - & - & - & - & - & 1 & 1 & $<1$ \\
\hline Amaranthaceae, seed & Amaranthaceae & - & - & - & - & - & - & 4 & 4 & 5 & 1 & 1 & 4 & 5 & 5 & 1 \\
\hline Amaranthaceae, leave & & - & - & - & 1 & 1 & 1 & 3 & 3 & - & - & - & - & 4 & 4 & 1 \\
\hline cf. Amaranthaceae, fg. of leaf & cf. Amaranthaceae & 14 & 14 & 2 & - & - & - & 93 & 93 & - & 16 & 16 & - & 123 & 123 & 29 \\
\hline Asphodel, seed & Asphodelus cf. tenuifolius & - & - & - & - & - & - & 1 & 1 & 1 & 2 & 2 & 1 & 3 & 3 & 1 \\
\hline
\end{tabular}




\begin{tabular}{|c|c|c|c|c|c|c|c|c|c|c|c|c|c|c|c|c|}
\hline Period & & \multicolumn{3}{|c|}{ Phase 1} & \multicolumn{3}{|c|}{ Phase 2} & \multicolumn{3}{|c|}{ Phase 3} & \multicolumn{3}{|c|}{ Phase 4} & \multicolumn{3}{|c|}{ Total } \\
\hline Dating & & \multicolumn{3}{|c|}{ c. $1000-500$ BCE } & \multicolumn{3}{|c|}{ c. 5th-6thC CE } & \multicolumn{3}{|c|}{$\begin{array}{c}\text { c. late 6th - 8thC } \\
\text { CE }\end{array}$} & \multicolumn{3}{|c|}{ c. 16 th-20thC CE } & & & \\
\hline Trenches & & \multicolumn{3}{|c|}{$\mathrm{B}, \mathrm{G}, \mathrm{N}$} & \multicolumn{3}{|c|}{$A, B, E$} & \multicolumn{3}{|c|}{$A, E, F, G$} & \multicolumn{3}{|c|}{$A, B, F, G$} & \multicolumn{3}{|c|}{$A, B, E, F, G, N$} \\
\hline Number of samples & & \multicolumn{3}{|c|}{7} & \multicolumn{3}{|c|}{6} & \multicolumn{3}{|c|}{15} & \multicolumn{3}{|c|}{12} & \multicolumn{3}{|c|}{40} \\
\hline Total of volume sieved (litre) & & \multicolumn{3}{|c|}{123} & \multicolumn{3}{|c|}{91.5} & \multicolumn{3}{|c|}{187.5} & \multicolumn{3}{|c|}{168.5} & \multicolumn{3}{|c|}{592.5} \\
\hline & & NR & MNI & $U$ & NR & $\mathrm{MNI}$ & $\mathrm{U}$ & NR & $\mathrm{MNI}$ & $\mathrm{U}$ & NR & MNI & $\mathrm{U}$ & NR & $\mathrm{MNI}$ & $\%$ \\
\hline Boraginaceae, nutlet & Boraginaceae & 28 & 28 & 7 & 23 & 23 & 4 & 50 & 50 & 13 & 21 & 21 & 7 & 122 & 122 & 29 \\
\hline Brassicaceae, seed & Brassicaceae & - & - & - & - & - & - & 2 & 2 & 2 & - & - & - & 2 & 2 & $<1$ \\
\hline cf. Brassicaceae, seed & cf. Brassicaceae & - & - & - & 1 & 1 & 1 & - & - & - & - & - & - & 1 & 1 & $<1$ \\
\hline Barnyard grass, caryopsis & Echinochloa cf. colona & - & - & - & - & - & - & 1 & 1 & 1 & - & - & - & 1 & 1 & $<1$ \\
\hline Euphorbiaceae, seed & Euphorbiaceae & - & - & - & - & - & - & 1 & 1 & 1 & - & - & - & 1 & 1 & $<1$ \\
\hline Und. pulse, seed & Fabaceae & - & - & - & - & - & - & 7 & 7 & 4 & 1 & 1 & 1 & 8 & 8 & 2 \\
\hline Und. pulse, cotyledon & & - & - & - & - & - & - & 3 & 2 & - & - & - & - & 3 & 2 & $<1$ \\
\hline Probable pulse, seed & cf. Fabaceae & - & - & - & 1 & 1 & 1 & 1 & 1 & - & - & - & - & 2 & 2 & $<1$ \\
\hline Probable helianthemum, seed & cf. Helianthemum & - & - & - & - & - & - & 1 & 1 & 1 & - & - & - & 1 & 1 & $<1$ \\
\hline Lamiaceae, seed & Lamiaceae & - & - & - & - & - & - & 1 & 1 & 1 & - & - & - & 1 & 1 & $<1$ \\
\hline Mallow, seed & Malva cf. parviflora & - & - & - & - & - & - & - & - & - & 1 & 1 & 1 & 1 & 1 & $<1$ \\
\hline Probable alfalfa, seed & cf. Medicago & - & - & - & - & - & - & 1 & 1 & 1 & - & - & - & 1 & 1 & $<1$ \\
\hline Probable alfalfa, fg. of seed & & - & - & - & - & - & - & 1 & 1 & - & - & - & - & 1 & 1 & $<1$ \\
\hline Sweet clover, seed & cf. Melilotus & - & - & - & - & - & - & 1 & 1 & 1 & - & - & - & 1 & 1 & $<1$ \\
\hline Millet, caryopsis & Panicoidae & - & - & - & - & - & - & 1 & 1 & 3 & - & - & - & 1 & 1 & $<1$ \\
\hline Probable millet, caryopsis & cf. Panicoïdae & - & - & - & - & - & - & 1 & 1 & - & - & - & - & 1 & 1 & $<1$ \\
\hline Probable millet, fg. of caryopsis & & - & - & - & - & - & - & 1 & 1 & - & - & - & - & 1 & 1 & $<1$ \\
\hline cf. Panicum, caryopsis & cf. Panicum & - & - & - & - & - & - & - & - & - & 1 & 1 & 1 & 1 & 1 & $<1$ \\
\hline Graminae, caryopsis & Poaceae & - & - & - & - & - & - & 1 & 1 & 2 & - & - & - & 1 & 1 & $<1$ \\
\hline Graminae, caryopsis with chaff & & - & - & - & - & - & - & 2 & 2 & - & - & - & - & 2 & 2 & $<1$ \\
\hline Graminae, fg. of caryopsis & & - & - & - & - & - & - & 1 & 1 & - & 1 & 1 & 1 & 2 & 2 & $<1$ \\
\hline Salsola, seed & Salsola sp. & - & - & - & 1 & 1 & 1 & 1 & 1 & 1 & 2 & 2 & 1 & 4 & 4 & 1 \\
\hline Foxtail, caryopsis & Setaria sp. & - & - & - & - & - & - & 1 & 1 & 1 & - & - & - & 1 & 1 & $<1$ \\
\hline Solanaceae, fg. of seed & Solanaceae & - & - & - & - & - & - & 1 & 1 & 1 & - & - & - & 1 & 1 & $<1$ \\
\hline Indeterminate & & & & & & & & & & & & & & & & \\
\hline Indeterminate, seed & & 10 & 10 & 4 & 2 & 2 & 2 & 38 & 38 & 6 & 14 & 14 & 6 & 64 & 64 & 15 \\
\hline
\end{tabular}




\begin{tabular}{|c|c|c|c|c|c|c|c|c|c|c|c|c|c|c|c|}
\hline Period & \multicolumn{3}{|c|}{ Phase 1} & \multicolumn{3}{|c|}{ Phase 2} & \multicolumn{3}{|c|}{ Phase 3} & \multicolumn{3}{|c|}{ Phase 4} & \multicolumn{3}{|c|}{ Total } \\
\hline Dating & \multicolumn{3}{|c|}{ c. 1000 - 500 BCE } & \multicolumn{3}{|c|}{ c. 5th-6thC CE } & \multicolumn{3}{|c|}{$\begin{array}{l}\text { c. late 6th - 8thC } \\
\text { CE }\end{array}$} & \multicolumn{3}{|c|}{ c. 16 th-20thC CE } & & & \\
\hline Trenches & \multicolumn{3}{|c|}{$\mathrm{B}, \mathrm{G}, \mathrm{N}$} & \multicolumn{3}{|c|}{$A, B, E$} & \multicolumn{3}{|c|}{$A, E, F, G$} & \multicolumn{3}{|c|}{$A, B, F, G$} & \multicolumn{3}{|c|}{$A, B, E, F, G, N$} \\
\hline Number of samples & \multicolumn{3}{|c|}{7} & \multicolumn{3}{|c|}{6} & \multicolumn{3}{|c|}{15} & \multicolumn{3}{|c|}{12} & \multicolumn{3}{|c|}{40} \\
\hline Total of volume sieved (litre) & \multicolumn{3}{|c|}{123} & \multicolumn{3}{|c|}{91.5} & \multicolumn{3}{|c|}{187.5} & \multicolumn{3}{|c|}{168.5} & \multicolumn{3}{|c|}{592.5} \\
\hline & NR & $\mathrm{MNI}$ & $U$ & NR & $\mathrm{MNI}$ & $U$ & NR & $\mathrm{MNI}$ & $U$ & NR & $\mathrm{MNI}$ & $U$ & NR & $\mathrm{MNI}$ & $\%$ \\
\hline Indeterminate, remains in arc & - & - & - & - & - & - & 24 & 24 & 2 & - & - & - & 24 & 24 & 6 \\
\hline Indeterminate, fg. of pericarp & - & - & - & - & - & - & - & - & - & 2 & 1 & 1 & 2 & 1 & $<1$ \\
\hline Indeterminate, spine & - & - & - & - & - & - & 8 & 8 & 2 & - & - & - & 8 & 8 & 2 \\
\hline Organic amorphous remains & $x$ & $x$ & 2 & $x$ & $x$ & 1 & - & - & - & $x$ & $x$ & 1 & $x$ & $x$ & - \\
\hline \multicolumn{16}{|l|}{ Coprolites } \\
\hline Coprolites, rodent dropping & 1 & 1 & 1 & - & - & - & 1 & 1 & 1 & - & - & - & 2 & 2 & - \\
\hline Coprolites, sheep/goat pellet & - & - & - & - & - & - & 4 & 4 & 2 & - & - & - & 4 & 4 & - \\
\hline cf. Coprolites & 1 & 1 & 1 & - & - & - & 1 & 1 & 1 & - & - & - & 2 & 2 & - \\
\hline $\begin{array}{l}\text { Total of determined carpological } \\
\text { remains }\end{array}$ & 18 & 18 & 7 & 32 & 32 & 5 & 204 & 199 & 15 & 54 & 52 & 10 & 336 & 329 & 77 \\
\hline $\begin{array}{l}\text { Total of undetermined carpological } \\
\text { remains }\end{array}$ & 10 & 10 & 5 & 2 & 2 & 3 & 70 & 70 & 8 & 16 & 15 & 8 & 98 & 97 & 28 \\
\hline Total of carpological remains & 28 & 28 & 7 & 34 & 34 & 6 & 274 & 269 & 15 & 70 & 67 & 12 & 434 & 426 & 100 \\
\hline
\end{tabular}

Table 2: General results of seed and fruit analysis per phase. NR = Number of Rests; MNI = Minimum Number of Individuals; fg. = fragment; $U$ = Ubiquity; \% = Percentages.

Ubiquity has been defined by taxon 


\subsection{Charcoal analysis}

Among 591 analysed charcoal fragments, 551 could be identified to the species or genus level (Table 3). 40 others could only be identified to the larger Angiosperm group or remained indeterminate, including bark fragments. 102 charcoal fragments (17\% of the total assemblage, indeterminate included) belong to one single Iron Age sample, 30 fragments (5\%) come from one Late Sasanian sample, and 459 fragments (78\%) from five contexts belonging to the Early Islamic Period. A total of eleven taxa have been determined botanically among which six to the species level and five to the genus level. Two main categories of woody plants can be distinguished: indigenous wild trees and shrubs $(\mathrm{N}=8)$ and cultivated fruit trees $(\mathrm{N}=2)$, although the precise status - wild or cultivated? - of some taxa requires further consideration (Figures $\mathbf{7}$ and $\mathbf{8}$ ).

Tamarisk (Tamaris sp.) is the dominant taxon (20\%), mostly concentrated in the Iron Age hearth (G.014), probably indicating that all the charcoals come from the same piece of wood associated with the last episodes of burning. Tamarisk is a hardy tree that can withstand both drought and flooding by growing in or on the edges of wadis. They are also salt-tolerant and thus found on saline soils in coastal areas and are planted as sand-stabilizers and wind-breaks near date palm gardens (Ghazanfar 2003: 120-122). Date palm (Phoenix dactylifera) is the second most represented taxon (19\%), including petiole remains. They are mainly concentrated in the Early Islamic hearth (A.014) showing the use of petiole as fuel, as already seen in the Arabian Peninsula (Bouchaud et al. 2012). Several taxa are main components of the vegetation cover typical of plains and foothills of Southeast Arabia such as prosopis (Prosopis cf. cineraria) (19\%), Christ's Thorn jujube tree (Ziziphus cf. spina-christi) (10\%), and acacia (Acacia sp.) (5\%) (Ghazanfar 2007: 6-11, 98-99). Jujube can also grow as cultivated fruit trees in gardens. The high concentration of prosopis and acacia charcoal in the Early Islamic oven is notable (F.047). Other elements of the vegetation belong to taxa mainly attested in the foothills and in mountainous areas but are present in the assemblage in minor proportions. These include xerophytic (drought-tolerant) shrubs such as Grewia sp. (2\%), Periploca sp. (1\%) and cf. Pergularia tomentosa (<1\%) (Ghazanfar 2007: 12-18, Ghazanfar 2003: 91-93). Some taxa are also attested as parts of hygrophilous formations growing in and near wadis or irrigated channels, like the Nile Acacia (Acacia cf. nilotica) (1\%) and willow (Salix cf. acmophylla) (<1\%) (Ghazanfar 2007: 11, Ghazanfar 2003: 129-130). For the latter, it is actually difficult to determine if it is indigenous or introduced since it is rarely observed today and mostly where it does occur, it is close to villages. 

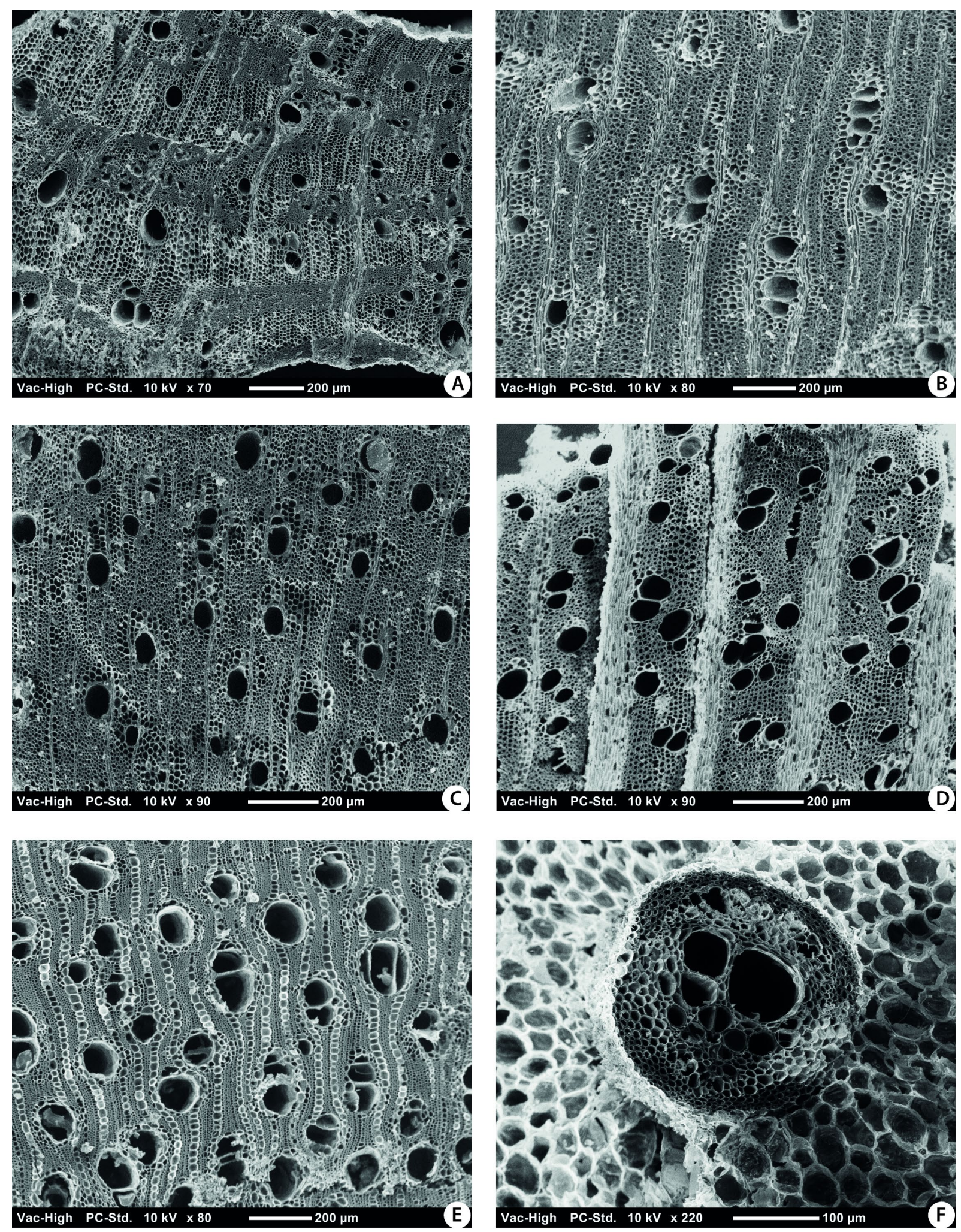

Figure 7: Charcoal remains from Fulayj fort (SEM photographs) (1/2). A: Acacia sp., transverse section; B: Acacia cf. nilotica, transverse section; C: Prosopis cf. cineraria, transverse section; D: Tamarix sp., transverse section; E: Ziziphus cf. spina-christi, transverse section; F: Phoenix dactylifera (petiole), transverse section. 

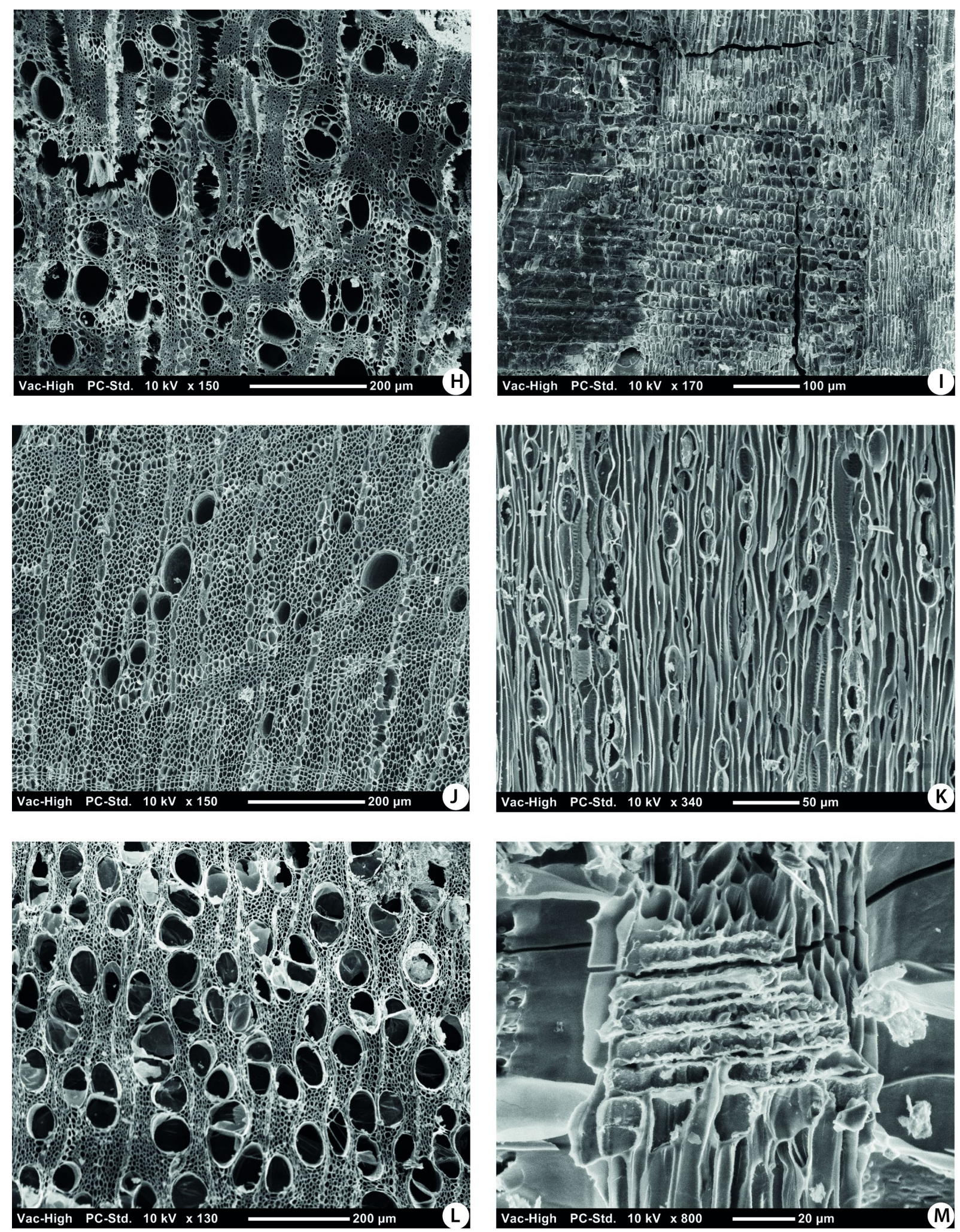

Figure 8: Charcoal remains from Fulayj fort (SEM photographs) (2/2). H-I: Grewia sp., transverse $(\mathrm{H})$ and longitudinal radial (I) section; J-K: Periploca sp., transverse (J) and longitudinal tangential (K) section; Willlow (Salix sp.) (L-M), transverse (L) and longitudinal radial (M) section. 


\begin{tabular}{|c|c|c|c|c|c|c|c|c|c|c|}
\hline Period & & Phase 1 & Phase 2 & \multicolumn{5}{|c|}{ Phase 3} & \multicolumn{2}{|c|}{ Total } \\
\hline Dating & & c. $1000-500$ & c. 5th-6thC & \multicolumn{5}{|c|}{ c. late 6th - 8thC CE } & & \\
\hline Trench & & $\mathrm{G}$ & B & A & A & $\mathrm{F}$ & $\mathrm{F}$ & $\mathrm{F}$ & \multicolumn{2}{|c|}{$A, B, F, G$} \\
\hline Context & & G.014 & B.007 & A.014 & A.016 & F.026 & F.030 & F.047 & \multicolumn{2}{|c|}{7} \\
\hline Volume (litres) & & 10 & 22 & 20 & 18 & 15 & 3 & 11 & \multicolumn{2}{|c|}{99} \\
\hline Vernacular name & Latin name & & & & & & & & NR & $\%$ \\
\hline Acacia & Acacia sp. & - & 1 & - & 2 & - & 3 & 6 & 12 & 2 \\
\hline Probable acacia & cf. Acacia & - & - & - & - & 11 & - & 4 & 15 & 3 \\
\hline Nile acacia & Acacia cf. nilotica & - & 1 & - & - & - & - & 6 & 7 & 1 \\
\hline Acacia/Prosopis & Acacia/Prosopis & - & 2 & - & - & 38 & 17 & 28 & 85 & 14 \\
\hline Grewia sp. & Grewia sp. & - & - & - & - & - & - & 13 & 13 & 2 \\
\hline $\begin{array}{l}\text { Probable Pergularia } \\
\text { tomentosa }\end{array}$ & $\begin{array}{c}\text { cf. Pergularia } \\
\text { tomentosa }\end{array}$ & - & - & - & - & - & 1 & - & 1 & $<1$ \\
\hline Periploca sp. & Periploca sp. & - & - & - & - & 5 & - & 3 & 8 & 1 \\
\hline Date palm, petiole & $\begin{array}{c}\text { Phoenix } \\
\text { dactylifera }\end{array}$ & - & - & 35 & 3 & 3 & - & 2 & 43 & 7 \\
\hline Date palm, indeterminate & $\begin{array}{c}\text { Phoenix } \\
\text { dactylifera, } \\
\text { indeterminate }\end{array}$ & - & - & 70 & 2 & - & - & - & 72 & 12 \\
\hline Willow & $\begin{array}{c}\text { Salix cf. } \\
\text { acmophylla }\end{array}$ & - & - & - & - & - & 1 & - & 1 & $<1$ \\
\hline Prosopis & $\begin{array}{c}\text { Prosopis cf. } \\
\text { cineraria }\end{array}$ & - & 2 & - & - & 43 & 17 & 20 & 82 & 14 \\
\hline Probable prosopis & cf. Prosopis & - & - & - & - & - & 22 & 9 & 31 & 5 \\
\hline Tamarisk & Tamarix sp. & 75 & 21 & - & 13 & 1 & 7 & - & 117 & 20 \\
\hline Probable tamarisk & cf. Tamarix & - & - & - & - & - & 3 & - & 3 & 1 \\
\hline Jujube tree & $\begin{array}{c}\text { Ziziphus cf. spina- } \\
\text { christi }\end{array}$ & 27 & - & - & 2 & 1 & 29 & - & 59 & 10 \\
\hline Probable jujube tree & cf. Ziziphus & - & - & - & - & - & 2 & - & 2 & $<1$ \\
\hline Angiosperm dicotyledon & & - & 2 & - & 8 & - & 5 & 2 & 17 & 3 \\
\hline $\begin{array}{l}\text { Angiosperm dicotyledon, } \\
\text { bark }\end{array}$ & & - & - & - & - & - & - & 11 & 11 & 2 \\
\hline
\end{tabular}




\begin{tabular}{|c|c|c|c|c|c|c|c|c|c|}
\hline Indeterminate & - & 1 & - & - & 3 & 8 & - & 12 & 2 \\
\hline $\begin{array}{l}\text { Total of determined } \\
\text { charcoals }\end{array}$ & 102 & 27 & 105 & 22 & 102 & 102 & 91 & 551 & 93 \\
\hline $\begin{array}{l}\text { Total of indetermined } \\
\text { charcoals }\end{array}$ & 0 & 3 & 0 & 8 & 3 & 13 & 13 & 40 & 7 \\
\hline Total of charcoals & 102 & 30 & 105 & 30 & 105 & 115 & 104 & 591 & 100 \\
\hline
\end{tabular}

Table 3: Results of the charcoal analysis. 


\subsection{Radiocarbon dating}

The sample of sorghum from context E.024 provided an age of $1175 \pm 20 \mathrm{BP}$, corresponding to a calibrated range of between 772 and $950 \mathrm{Cal}$. CE, at 2 sigma or $95.4 \%$ probability (Figure 9 and Table 4). The charred twig of Tamarix from the same context provides an AMS date of $1306 \pm 22$ BP, corresponding to a calibrated range of between 660 and 775 Cal. CE at 2 sigma or $95.4 \%$ probability. The piece of Tamarix wood from context (F.036) provided an AMS date of $1405 \pm 28$ BP with a calibrated range of between 601 and 664 Cal. CE at 2 sigma or $95.4 \%$ probability (calibration IntCal2020, Reimer et al. 2020).

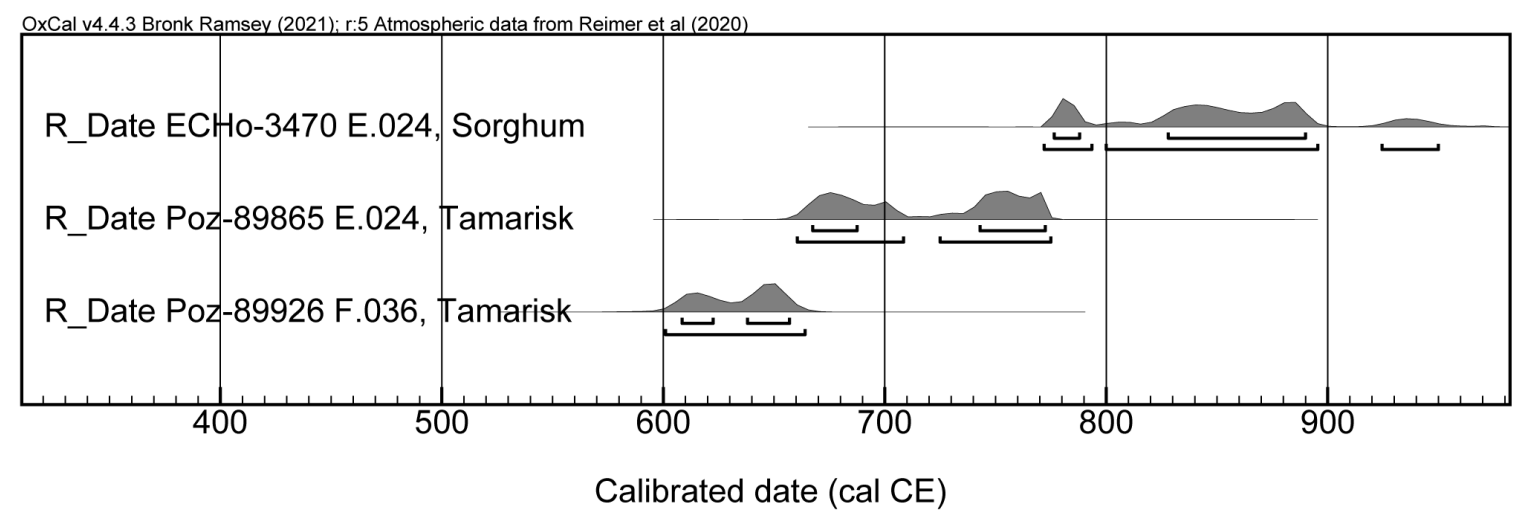

\begin{tabular}{|c|c|c|c|c|c|c|c|}
\cline { 6 - 8 } Context & Find N & Lab N & Sample description & $\mathbf{1 4 C}$ age & Error & $\mathbf{6 8 . 2 \%}$ & $\mathbf{9 5 . 4 \%}$ \\
\hline E.024 & - & ECHo-3470.1.1 & Sorghum caryopsis & 1175 & 20 & $776-890$ & $772-950$ \\
\hline E.024 & FN246 & Poz-89865 & Tamarisk twig & 1306 & 22 & $667-772$ & $660-775$ \\
\hline F.036 & SN20 & Poz-89926 & Tamarisk & 1405 & 28 & $608-657$ & $601-664$ \\
\hline
\end{tabular}

Table 4: Detailed results of AMS dating included in this paper.

\section{Discussion}

\subsection{Trade versus local cultivation of sorghum}

If we exclude the claim for the 3rd mill. BCE presence of sorghum at Hili 8 (Cleuziou 1982, Cleuziou and Costantini 1982, see above) that has been questioned by several authors (Bouchaud et al. 2016, Tengberg 2012, Charbonnier 2008, de Moulins et al. 2003), the evidence from Fulayj represents the earliest securely identified and dated occurrence of sorghum in Eastern Arabia. The direct dating of sorghum from context E.024 is slightly later than the tamarisk twig from the same deposit and may testify to a longer occupation at Fulayj fort during the Early Islamic period than initially thought. In addition, the two glass fragments found in this context (E.024/FN234 and FN251) appear consistent with a date within the c. 7th/8th century. A later date within the 9th or 10th century, that the absolute dating of the sorghum material would potentially allow, seems unlikely on archaeological grounds as there is a complete absence of characteristic 9 th or 10th century ceramics from anywhere within the excavations or across the surrounding landscape. Furthermore, it is relevant to consider the archaeological dating of sorghum within the fort in context F.036, which indicates the presence 
of the crop most likely within the first half of the 7th century according to the material found within this context including the AMS dating evidence. The context is certainly dated before the later 8th century since it is stratigraphically sealed by the construction of an oven (F.026) above dated to 1295 \pm BP (664-774 Cal. CE at $94.5 \%$ probability). Therefore, sorghum from Fulayj is clearly dated with the period immediately following the conversion to Islam.

The evidence of sorghum from Fulayj raises the question about the origin of this crop; whether it corresponds to an imported trade item, or if it was locally acclimatised and cultivated. In the former case, both East Africa and India are relevant candidates as sources since sorghum is known to have been grown in both these areas at this time. Textual references, although scarce, mention trade activities between Oman and these regions in the Early Islamic period. The integration of Omani harbours, like Sohar, within the international trade networks of the western Indian Ocean therefore created a favourable context for the import of new food products to Fulayj. While it remains difficult to determinate the region of origin of sorghum, the presence of other cultural materials such as South Asian pottery at Fulayj (al-Jahwari et al. 2018), may point in favour of the Indian sub-continent. However, Yemen might also be considered as potential source of origin. Indeed, archaeobotanical evidence of sorghum grains and glumes in sheep and camel coprolites are found at Zabid (9th to 10th century) (McCorriston and Johnson 1998) and later Rasulid textual references mention numerous local varieties of sorghum in Yemen during the 14th century (Varisco and Umar Ibn Yusuf 1994: 165, Varisco 1991). Whatever the origin, the presence of sorghum at Fulayj sheds important new light on potential routes of supply and the dissemination of novel food commodities via processes of longdistance maritime exchange during the Early Islamic period.

An alternative explanation for the presence of sorghum at Fulayj is local acclimatisation of an exogenous crop. This drought-resistant cereal is well-adapted to local climatic conditions in Oman, where the hot summer temperatures would have suited its ecological requirements. According to Ulbaydli (1993), the Jāmi' of Ibn Ja'far (iii. 35), an author of the Omani Ibadi jurisprudence living in the 9th century, refers to the cultivation of sorghum in Oman during the Early Islamic period potentially adding to the available archaeological evidence. However, we were not able to get access to the original arabic mention of the Jāmi' of Ibn Ja'far so far so we have to be cautious about its accuracy. Nowadays, sorghum has been recorded growing on the Batinah coast (Esechie 1994). The two earth impressions found at Fulayj appear to favour the hypothesis of local acclimatisation. Indeed, these impressions may be explained by the accidental inclusion of grains together with byproduct material in mudbrick architecture. The use of cereal chaff as a temper in earthen building materials is usually an indication of local cultivation, even though the trade in chaff cannot be entirely ruled out. In conclusion, the evidence of sorghum in Fulayj may thus testify to the introduction of sorghum agriculture in Eastern Arabia during the Early Islamic period although supplementary data would be needed in order to confirm this hypothesis. In either case, the import of sorghum as a foodstuff, or the translocation of a new crop and its addition to the repertoire of local agriculture during the Early Islamic period, would have depended on the vehicle of longdistance exchange to gain access to what appears to have been a new food commodity in the region.

\subsection{Plant diet and oasis agriculture}

Archaeobotanical remains provide a crucial insight into certain aspects of diet and food production systems. In addition to the new evidence for sorghum, recovered staples include cereals with freethreshing wheat during the Iron Age and, hulled barley during the Late Sasanian and Early Islamic period. Free-threshing wheat and hulled barley are attested in Eastern Arabia since at least the Early Bronze Age (3rd millennium BCE) mainly in the form of chaff impressions on mudbrick (Willcox 1995, Willcox and Tengberg 1995, Cleuziou 1982). Well-preserved mudbrick impressions of free-threshing 
wheat chaff (glumes and rachis segments) correspond to the bread wheat type. In addition, the Iron Age site of Salut (Sultanate of Oman) has produced evidence of a single grain of Triticum sp. and pollen of Triticum and Hordeum groups (Bellini et al. 2011). A contemporary example of hulled barley is also attested at Kush (UAE) in the Sasanian and Early Islamic levels. Moreover, undetermined pulses are present at Fulayj during the Late Sasanian period. The first evidence of pulses in Eastern Arabia has been reported from the Bronze Age site Hili 8 as pea (Pisum sativum) (Tengberg 2012). The Sasanian contexts of the site of Kush have yielded some lentil (Lens culinaris ssp. culinaris) and grass pea (Lathryrus sativus) (Dabrowski 2019: 174-197, Dabrowski et al. forthcoming).

Fruits constitute another part of the plant diet with dates represented throughout the occupational sequence and jujubes attested in particular during the Early Islamic period. The earliest evidence for date consumption in Southeast Arabia comes from the site of Dalma 11 in the Emirate of Abu Dhabi (UAE) and dates to the late 6th to early 5th millennium BCE (Beech and Shepherd 2001). Date palm remains increase from the Bronze Age onwards (Tengberg 2012) and are well attested on several Iron Age sites (Cerro 2013, Bellini et al. 2011, Tengberg 1998, Willcox and Tengberg 1995, Costantini and Costantini-Biasini 1986). The earliest occurrence of jujube in archaeological contexts corresponds to an abundant find of about 300 fruit stones on the Neolithic sites of Ra's al-Hamra H5 and RH6 (5th to early 3rd millennium BCE) in Oman showing the gathering of the edible fruits since prehistoric times (Biagi and Nisbet 1999, 1992). Both dates and jujubes are attested in Sasanian and Early Islamic levels at Kush, the former as the most dominant fruit tree (Dabrowski 2019: 174-197, Dabrowski et al. forthcoming).

The general composition of archaeobotanical assemblages together with climatic data may provide information on the organisation of local crop cultivation. The predominance of date palm remains (seeds and petiole fragments) indicates the existence of date palm gardens during all periods of occupation. Modern oases in the Middle East are vertically organised with date palms forming the upper level and providing shade to other fruit trees and annual crops cultivated in irrigated plots below the canopy (Battesti 2005, Munier 1973). The recurrent association of date and cereal remains in contexts where rainfed agriculture is excluded suggests that agriculture was practised in date palm gardens in Eastern Arabia since at least the 3rd millennium BCE (Tengberg 2012). Some of the weedy/wild taxa found at Fulayj associated mostly with the Early Islamic contexts correspond to weeds growing in current irrigated fields (Ghazanfar 2007, 2003). Hygrophilous trees attested among the charcoal assemblages (tamarisk, Nile acacia, willow) may have been planted along irrigation channels in the date palm gardens; tamarisk could have also been established as wind-breaks or to stabilise the soil at the edges of plantations. The presence of one charcoal of willow dating to the Early Islamic period may represent further evidence for irrigation since, in the hot climate of Eastern Arabia, this tree would only grow along permanent watercourses or irrigation channels as observed today in the Sultanate of Oman (Ghazanfar 2003: 129-130). In the case of sorghum acclimatisation, it must have been incorporated in such an agrosystem where irrigation would have met its hydrological needs, as nowadays it is grown in low-altitude mountain oases in the northern part of the Sultanate of Oman (Gebauer et al. 2007, Guarino 1990).

\subsection{Local or regional plant acquisition strategies?}

Date palm gardens may have been located near to the fort as is the case today. As already noted above, groundwater tables on the Batinah plain are too deep to be reached through wells outside the coastal area (Wilkinson 1977: 48-49). Today's date palm gardens surrounding the adjacent village of Falaj Al-Harth are fed with water provided via afläj; underground galleries or irrigation channels, that capture the water upstream where the flow is still close to the surface. Initially, the Sasanian period was thought to have been a period of extensive development of irrigation systems with aflāj 
attested in the hinterland of Sohar but these have more recently proved to date to the Islamic period (Costa and Wilkinson 1987: 54, Wilkinson 1977: 130-133). Several open irrigation channels have been excavated in the vicinity of Fulayj fort (Figure 10) and may have been used for agricultural purposes. OSL dating of selected channels indicates construction during the Late Islamic period (Snape Kennedy 2018), though the possibility of earlier irrigation systems cannot be excluded on the basis of this evidence. Similar open irrigation channels and aflāj are attested with certainty since the Iron Age in Southeast Arabia (Charbonnier 2017, 2015), and their use for watering date palm gardens at Fulayj too appears likely. Moreover, the presence of woody tissues from date palm in the assemblage, notably in an Early Islamic hearth (A.014), indicates that its by-products such as petiole were commonly used as fuel as demonstrated in other charcoal analyses in the Arabian Peninsula (Bouchaud et al. 2012). So, the evidence indicates that date palm gardens, in addition to producing staple food crops, also generated valuable by-products in the form of fuel resourses that were also regularly exploited during the occupation of Fulayj.

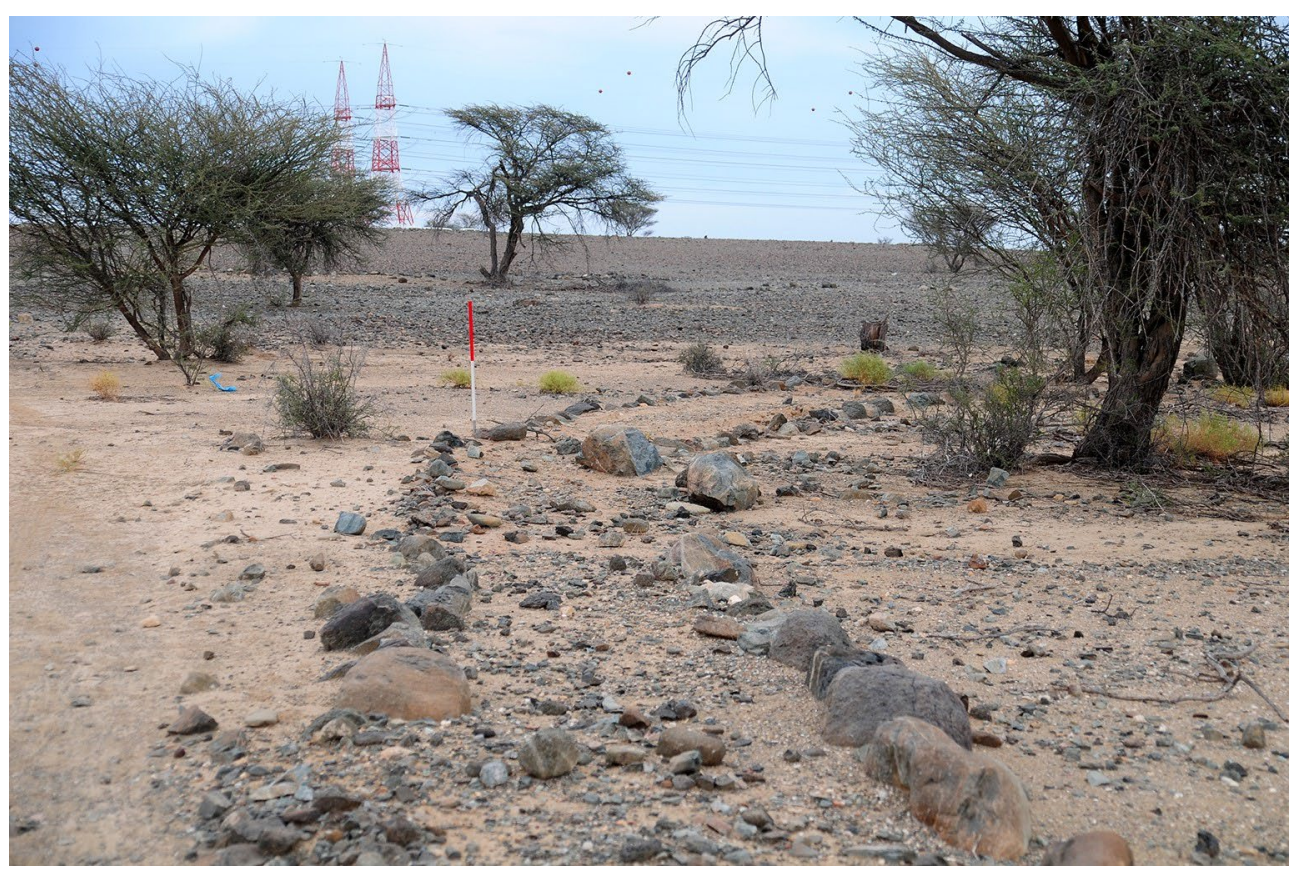

Figure 10: Open irrigation channel close to Fulayj dated by OSL to the Late Islamic period. (This figure should be in colour)

While locally available plant resources clearly played a dominant part, it is also important to keep in mind the possibility of the use of wider regional supply strategies, particularly within the military context of the fort's initial foundation. Indeed, some areas of the Batinah plain may be considered as more desirable for establishing agricultural systems. Today date palms gardens are mostly concentrated close to the coast (Figure 11), which has edaphic and hydrologic advantages compared to Fulayj (Sanlaville 2000: 140-141, Wilkinson 1977: 48-49). This hypothesis of regional food supply systems could be further supported if the fort was part of a wider defensive and military network (Kennet et al. 2016). These ideas feed into the notion of increasing Sasanian involvement in agrarian activities on the Batinah suggested by some textual references, maybe by the time of Khusraw 1 during the 6th century (Wilkinson 2010: 57-60, Wilkinson 1979: 888-889, Wilkinson 1977: 130-133). Such a production system may have been complemented by more local initiatives closer to the fort as is suggested by the evidence discussed above. Food supply (for example, cereals) from more distant regions belonging to the Sasanian Empire is also possible. The predominance of imported 
pottery at Fulayj from sources in southern Mesopotamia and Iran could be taken as one potential indication of a regular system of external provisioning.

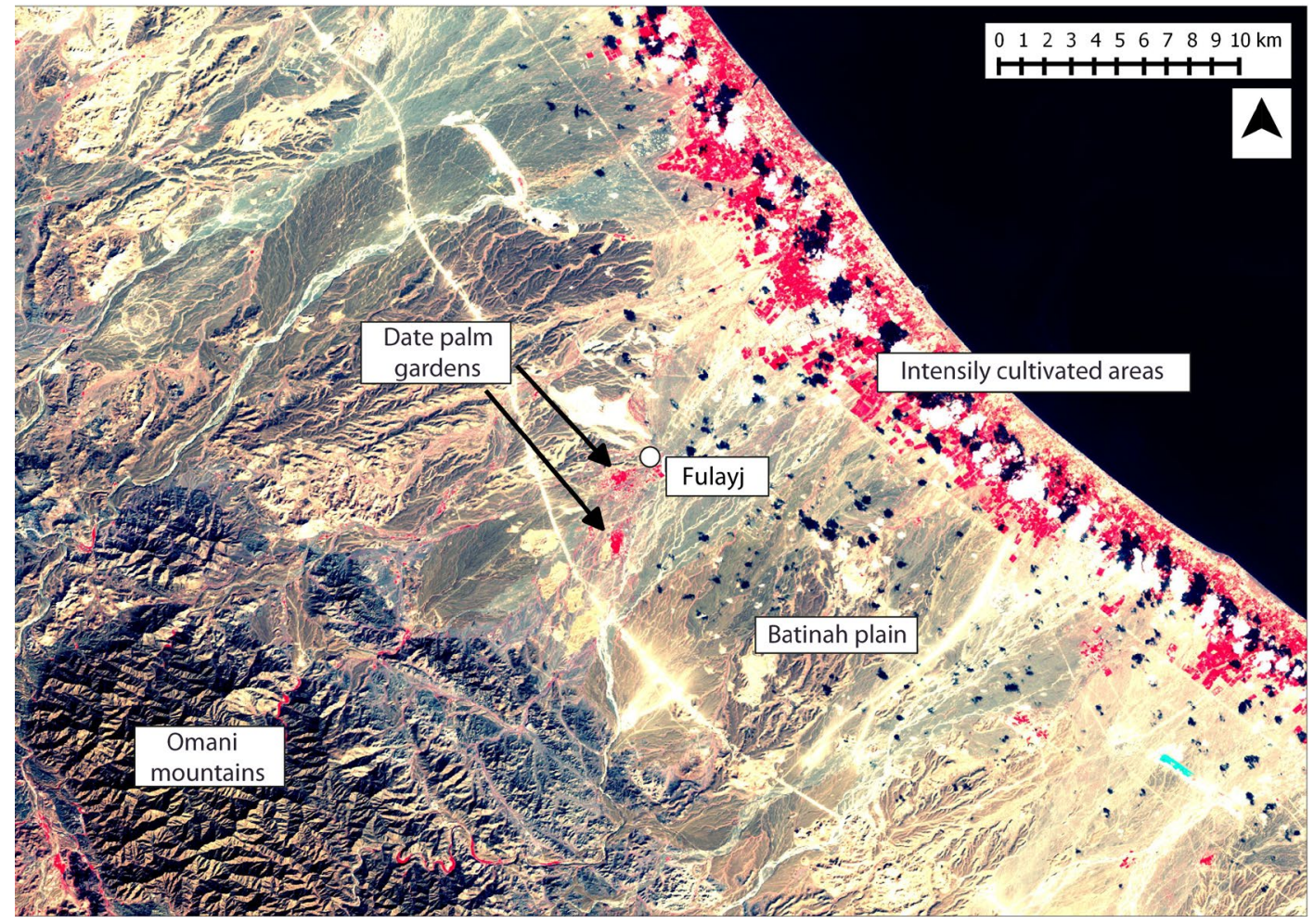

Figure 11: Satellite photograph with repartition of date palm gardens in the Batinah plain. Date palm gardens are mainly concentrated today in the coastline sector. (This figure should be in colour)

The predominance of locally grown trees in the charcoal record indicates that most of the fuel wood was collected within the vicinity of the site, mostly from open dry woodlands dominated by acacia (Acacia spp.) and jujube trees (Ziziphus cf. spina-christi) as well as prosopis (Prosopis cf. cineraria) on deeper soils. Tamarisk wood (Tamarix sp.) may have been collected along wadis and field edges. The presence of large acacia and prosopis charcoal fragments in samples from the Early Islamic period oven within the northeast corner of the fort (F.026, F.047) may result from their selection for calorific properties or their suitability for charcoal production (Fagg and Stewart 1994, Leakey and Last 1980). The absence of Amaranthaceae among the charcoal assemblage, while some potential leaf fragments have been recovered, is quite surprising. Shrubs from the Amaranthaceae family should have grown near the site, and their wood elements might have been used as fuel. Methodological issues connected with sampling or taphonomic factors may explain their absence but this question deserves further investigation.

That the catchment area for firewood extended somewhat beyond the immediate surroundings of the site is indicated by the presence in Early Islamic samples of shrub species such as Grewia sp., cf. Pergularia tomentosa and Periploca sp., that are more likely to have grown in the foothill zone or in the mountains. Periploca, for example, does not grow today below $500 \mathrm{~m}$ asl in the mountains of Oman. The woody parts of shrubs may also have been brought to the site as by-products of other exploitation processes. For example, we can cite the case of Grewia whose edible fruits are gathered for human consumption and its foliage as fodder or even Pergularia tomentosa and Periploca that can be used for medical treatments (Ghazanfar 2007: 12-18, Ghazanfar 2003: 91-93). However, the present vegetation cover is highly degraded and taxa that today grow only in the foothill zone possibly had a wider distribution in the past. 


\section{Conclusions}

The archaeobotanical analysis conducted at the site of Fulayj documents the food and fuel acquisition strategies in this arid environment during the Late Sasanian and Early Islamic periods which are still under-represented in Eastern Arabia. The first direct dating of sorghum to the Early Islamic period makes it the earliest securely identified occurrence of this crop in the region. This warm and drought-resistant cereal may have been introduced to the site either in the form of an imported food commodity via long-distance exchange from areas such as the Indian sub-continent, Africa or Yemen, or have been introduced from these sources and acclimatized locally as is potentially indicated by earth impressions of sorghum grains.

In addition to sorghum, the main components of the plant diet have been defined as cereals (hulled barley, free-threshing wheat during the Iron Age) and fruits (date, jujube). The composition of the whole assemblage shows that the agricultural system, which provided food and fuel products, is constructed around the use of date palm gardens; an oasis agrosystem typical of arid and semi-arid environments of the Middle East, attested in Eastern Arabia since the 3rd millennium BCE. In the case of acclimatization, sorghum is likely to have been grown within this agrosystem as is seen nowadays in the Omani mountains.

Date palm gardens were probably established close to the site, as they are today, as is suggested by the associated archaeobotanical remains. However, agricultural systems may also have been maintained in the shoreline sector of the Batinah plain where soil factors and hydrological conditions are better suited to agriculture, maybe within the framework of regional scale food supply systems organised by foreign political authorities. Fuel management practices at Fulayj include the exploitation of locally available species (acacia, prosopis, jujube tree, tamarisk) together with firewood gathering from the foothills and surrounding mountainous areas.

The archaeobotanical assemblage obtained as part of the archaeological investigation of Fulayj provides substantial complementary information that helps us to understand the functioning of the site. Against the background of political and religious transformation between the 5th to 8th centuries, subsistence economies seem on the contrary to be underpinned by long-term factors of continuity and well adapted strategies to local ecological conditions. The establishment of palm garden cultivation and fixed irrigation infrastructure, in particular, suggests a significant degree of long-term planning and investment, and perhaps also, helps to explain the seeming longevity of occupation at Fulayj. At the same time, crucial evidence emerges for aspects of innovation and adaptation closely associated with the existence of long-distance maritime exchange networks. While the archaeobotanical evidence still remains relatively limited and partial, it does suggest important new avenues for investigation within the region. This includes potential alternative pathways to the transformation of society in Eastern Arabia during the later 1st millennium CE based on the development of innovative agricultural strategies capable of bolstering dietary resilience and diversity.

\section{Acknowledgements}

We would like to extent our particular thanks to the Ministry of Heritage and Culture of the Sultanate of Oman for supporting our work and especially to Sultan Al-Bakri, Director of the Department of Excavations and Archaeological Studies. We are also particularly grateful to the directors of the Fulayj Fort Project: Dr. Nasser Saïd al-Jahwari (Department of Archaeology, Sultan Qaboos University) who first identified the site of Fulayj and helped in many ways to facilitate our work; Dr. Derek Kennet (Department of Archaeology, Durham University) for support and guidance throughout the study; and, Prof. Eberhard Sauer (School of History, Classics and Archaeology, University of Edinburgh) for 
integrating the investigation of Fulayj into the European Research Council funded Persia and its Neighbours Project. We would like also to thank Enki Baptiste (Université Lumière Lyon 2) and Dr. Harry Munt (Department of History, University of York) for their help with investigating textual mentions of sorghum in Ibadi sources. We would like to thank the doctoral college of Sorbonne Universités who granted the first author a PhD fellowship which permit the archaeobotanical analysis. Work was directed in the field by Dr. Seth Priestman. Processing of the archaeobotanical assemblage was undertaken by Dr. Vladimir Dabrowski and made possible by the efforts of the entire fieldwork team.

\section{References}

al-Abdali, S., A. Al-Dhuhli, and H. Al-Reasi. 2019. « Preliminary Investigations of Allelopathic Effects and Herbicide-Based Eradication of Mesquite (Prosopis Juliflora) ". Sultan Qaboos University Journal for Science 24 (1): 11-17. https://doi.org/10.24200/squjs.vol24iss1pp11-17.

Abdelrahman, H. A., A. Lepiece, and V. Macalinga. 1993. "Some physical and chemical characteristics of the Batinah soils ". Communications in Soil Science and Plant Analysis 24 (17-18): 22932305. https://doi.org/10.1080/00103629309368956.

Abrams, M. J., and O. H. Chadwick. 1994. "Tectonic and climatic implications of alluvial fan sequences along the Batinah coast, Oman ». Journal of the Geological Society 151 (1): 51-58. https://doi.org/10.1144/gsigs.151.1.0051

Barron, A., D. Q. Fuller, C. Stevens, L. Champion, F. Winchell, and T. Denham. 2020. "Snapshots in time: MicroCT scanning of pottery sherds determines early domestication of sorghum (Sorghum bicolor) in East Africa ». Journal of Archaeological Science 123: 105259.

Battesti, V. 2005. Jardins au désert: Evolution des pratiques et savoirs oasiens - Jerid tunisien. A travers champs. Paris: I.R.D.

Beech, M., and E. Shepherd. 2001. "Archaeobotanical evidence for early date consumption on Dalma Island, United Arab Emirates ». Antiquity 75 (287): 83-89. https://doi.org/10.1017/S0003598X00052765

Beldados, A. 2019. "Millets in eastern Sudan: an archaeobotanical study ». Azania: Archaeological Research in Africa 54 (4): 501-15. https://doi.org/10.1080/0067270X.2019.1691844.

Bellini, C., C. Condoluci, G. Giachi, T. Gonnelli, and M. M. Lippi. 2011. "Interpretative scenarios emerging from plant micro- and macroremains in the Iron Age site of Salut, Sultanate of Oman ». Journal of Archaeological Science 38 (10): 2775-89. https://doi.org/10.1016/i.jas.2011.06.021.

Bellini, C., A. Pavan, L. Pignotti, T. Gonnelli, and M. M. Lippi. 2020. «Food Plants in Pollen Records from Ancient Southern Arabia: The Evidences from Sumhuram (Southern Oman) ». Journal of Arid Environments 177: 104131. https://doi.org/10.1016/i.jaridenv.2020.104131.

Biagi, P., and R. Nisbet. 1992. "Environmental history and plant exploitation at the aceramic sites of RH5 and RH6 near the mangrove swamp of Qurm (Muscat-Oman) ». Bulletin de la Société Botanique de France. Actualités Botaniques 139 (2-4): 571-578. https://doi.org/10.1080/01811789.1992.10827129

- - - 1999. "The shell-midden sites of RH-5 and RH-6 (Muscat, Sultanate of Oman) in their environmental setting ». Archaeologia Polona 37: 31-47.

Boivin, N., A. Crowther, M. Prendergast, and D. Q. Fuller. 2014. "Indian Ocean Food Globalisation and Africa ». African Archaeological Review 31 (4): 547-81. https://doi.org/10.1007/s10437014-9173-4.

Bouchaud, C., R. Thomas, and M. Tengberg. 2012. "The Multipurpose Date Palm "Tree": Anatomical Identification of Modern Palm Stems and Practical Application in the Archaeological Site of Madâ'in Sâlih (Saudi Arabia) ". SAGVNTVM Extra 11: 47-48.

Bouchaud, C., V. Dabrowski, and M. Tengberg. 2016. "Etat de la recherche archéobotanique en péninsule arabique ». Routes de l'Orient H-S 2: 21-37. 
Brinkmann, K., A. Patzelt, U. Dickhoefer, E. Schlecht, and A. Buerkert. 2009. « Vegetation patterns and diversity along an altitudinal and a grazing gradient in the Jabal al Akhdar mountain range of northern Oman». Journal of Arid Environments 73 (11): 1035-1045. https://doi.org/10.1016/i.jaridenv.2009.05.002

Bronk Ramsey, C. 2009. Bayesian analysis of radiocarbon dates. Radiocarbon 51 (1) : 337-360.

Cappers, R. T. J., R. M. Bekker, and J. E. A. Jans. 2006. Digitale zadenatlas van Nederland. Groningen archaeological studies 4. Eelde; Groningen: Barkhuis Publishing; Groningen University Library.

Cappers, R. T. J., R. Neef, and R. M. Bekker. 2009. Digital atlas of economic plants. Groningen archaeological studies 9. Groningen: Barkhuis and Groningen University Library.

-- - 2012. Digital atlas of economic plants in archaeology. Groningen archaeological studies 17. Groningen: Barkhus and Groningen University Library.

de Cardi, B. 1972. " A Sasanian outpost in northern Oman ». Antiquity 46 (184): 305.

de Cardi, B., C. Vita-Finzi, and A. Coles. 1975. « Archaeological Survey in Northern Oman, 1972 ». East and West 25 (1/2): 9-75.

Carter, R. 2008. "Christianity in the Gulf during the First Centuries of Islam ». Arabian Archaeology and Epigraphy 19 (1): 71-108. https://doi.org/10.1111/j.1600-0471.2008.00293.x.

Cerro, C. del. 2013. "Biological Remains at Al-Madam (Sharjah, UAE) Archaeological, Archaeobotanical and Archaeozoological Studies in an Iron Age Farming-Stockbreeding Village ". Bioarchaeology of the Near East 7: 21-32.

Chabal, L. 1997. Forêts et sociétés en Languedoc néolithique final, Antiquité tardive l'anthracologie, méthode et paléoécologie. Documents d'archéologie française 63. Paris: Maison des sciences de l'homme.

Chabal, L., L. Fabre, J.-F. Terral, and I. Théry-Parisot. 1999. " L'anthracologie ». In La botanique, ed. by A. Ferdière. Coll. « Archéologiques ». Paris: Errance.

Chantereau, J., J.-F. Cruz, A. Ratnadass, G. Trouche, and G. Fliedel. 2013. Le sorgho. Versailles: Quae.

Charbonnier, J. 2008. "L'agriculture en Arabie du Sud avant I'Islam ». Chroniques yéménites, $\mathrm{n}^{\circ} 15$ : 1-28. https://doi.org/10.4000/cy.1627

- - . 2015. "Groundwater management in Southeast Arabia from the Bronze Age to the Iron Age: a critical reassessment ». Water History 7 (1): 39-71. https://doi.org/10.1007/s12685-014$\underline{0110-x}$

- - - 2017. "The Genesis of Oases in Southeast Arabia: Rethinking Current Theories and Models ». In Oases and Globalisation, ed. by E. Lavie and A. Marshall. Springer Geography. https://doi.org/10.1007/978-3-319-50749-1 4

Clapham, A.J., and P.A. Rowley-Conwy. 2007. "New Discoveries at Qasr Ibrim, Lower Nubia ». In Fields of Change: Progress in African Archaeobotany, ed. by R.T.J. Cappers. Groningen: Groningen Institute of Archaeology.

Cleuziou, S. 1982. " Hili and the beginning of oasis life in eastern Arabia ". Proceedings of the Seminar for Arabian Studies, 15-22.

Cleuziou, S., and L. Costantini. 1982. « A I'origine des oasis ». La Recherche 13 (137): 1179-82.

Costa, P., and T. Wilkinson. 1987. « The Hinterland of Sohar ». Journal of Oman Studies 9: 102-38.

Costantini, L., and L. Costantini Biasini. 1986. "Laboratory of Bioarchaeology ». East and West 36 (4): 354-365.

Dabrowski, V., 2019. "Systèmes d'approvisionnement et gestion des ressources végétales en Arabie orientale aux périodes antique et islamique (IV ${ }^{\text {ème }}$ s. av. J.-C. - XVIème s. ap. J.-C.): approches archéobotanique et archéoentomologique ». Doctorat, Paris, France: Muséum national d'Histoire naturelle.

Dabrowski, V., J. Ros, M. Tengberg, and A. Rougeulle. 2015. "De l'origine et de l'utilisation des ressources végétales en Oman médiéval : première étude archéobotanique à Qalhât ». Routes de l'Orient, $\mathrm{n}^{\circ}$ 2: 1-13. 
Dabrowski, V., M. Tengberg, A. Parker, and D. Kennet. forthcoming. "Agricultural economy, plant use and trade on the Sasanian and Islamic site of Kush (Ra's al-Khaimah's Emirate, U.A.E) ». Vegetation History and Archaeobotany.

Daryaee, T. 2003. " The Persian Gulf trade in late antiquity ». Journal of World History 14: 1-16.

Deil, U., and A-N al-Gifri. 1998. "Montane and wadi vegetation". In Vegetation of the Arabian Peninsula, ed. by S.A. Ghazanfar and M. Fisher,125-174. Geobotany 25. Dordrecht London: Kluwer Academic. https://doi.org/10.1007/978-94-017-3637-4 6

Esechie, H. A. 1994. "Interaction of salinity and temperature on the germination of sorghum ». Journal of Agronomy and Crop Science 172 (3): 194-199.

Fagg, C. W., and J. L. Stewart. 1994. "The value of Acacia and Prosopis in arid and semi-arid environments ». Journal of Arid Environments 27 (1): 3-25. https://doi.org/10.1006/jare.1994.1041.

Fahn, A., and E. Werker. 1986. Wood anatomy and identification of trees and shrubs from Israel and adjacent regions. Ed. by P. Bass. Jerusalem: Israel Academy of Sciences and Humanities.

Fleitmann, D., Mudelsee, M., Bradley, R.S., Pickering, P., Kramers, J., Burns, S.J., Mangini, A., Matter, A., 2009. Megadroughts at the dawn of Islam recorded in a 2600-year long stalagmite from Northern Oman, in: EGU General Assembly 2009. Presented at the EGU General Assembly Conference Abstracts, p. 8174.

Fuller, D. Q. 2003. "African crops in prehistoric South Asia: a critical review ». Food, fuel and fields. Africa Praehistorica 15: 239-271.

-- - 2014. "Agricultural Innovation and State Collapse in Meroitic Nubia ". In Archaeology of African plant use, ed. by Ch. Stevens, S. Nixon, M.A. Murray, and D.Q. Fuller, 165-78. Publications of the Institute of Archaeology, University College London 61. Walnut Creek (Calif.): Walnut Creek (Calif.): Left Coast Press.

- - - 2017. "A Millet Atlas: Some Identification Guidance, 3rd edition ».

Fuller, D. Q., and N. Boivin. 2009. "Crops, cattle and commensals across the Indian Ocean. Current and Potential Archaeobiological Evidence ». Etudes Ocean Indien, $\mathrm{n}^{\circ}$ 42-43: 13-46. https://doi.org/10.4000/oceanindien.698

Fuller, D. Q., and C. J. Stevens. 2018. "Sorghum domestication and diversification: a current archaeobotanical perspective ". In Plants and People in the African Past, ed. by A. M. Mercuri, A. C. D'Andrea, R. Fornaciari, and A. Höhn, 427-452. Springer. https://doi.org/10.1007/978-3319-89839-1 19

Gebauer, J., E. Luedeling, K. Hammer, M. Nagieb, and A. Buerkert. 2007. «Mountain Oases in Northern Oman: An Environment for Evolution and in Situ Conservation of Plant Genetic Resources". Genetic Resources and Crop Evolution 54 (3): 465-81. https://doi.org/10.1007/s10722-006-9205-2.

Ghazanfar, S. A. 1991. "Vegetation Structure and Phytogeography of Jabal Shams, an Arid Mountain in Oman ». Journal of Biogeography 18 (3): 299-309. https://doi.org/10.2307/2845400.

- - . 1992. "Quantitative and Biogeographic Analysis of the Flora of the Sultanate of Oman ". Global Ecology and Biogeography Letters 2 (6): 189-95. https://doi.org/10.2307/2997660.

- - . 1996. «Invasive Prosopis in Sultanate of Oman ». Aliens 3: 10.

- - . 1998a. "Status of the flora and plant conservation in the Sultanate of Oman ». Biological Conservation 85 (3): 287-295. https://doi.org/10.1016/S0006-3207(97)00162-6

- - . 1998b. "Vegetation of the Plains ". In Vegetation of the Arabian Peninsula, ed. by S. A. Ghazanfar and M. Fisher, 175-90. Geobotany 25. Springer Netherlands. https://doi.org/10.1007/978-94-017-3637-4 7.

-- - 2003. Flora of the Sultanate of Oman. Vol. 1: Piperaceae - Primulaceae. Scripta botanica Belgica 25. Meise: National Botanic Garden (Belgium).

-- - 2007. Flora of the Sultanate of Oman. Vol. 2: Crassulaceae-Apiaceae. Vol. 36. Scripta Botanica Belgica.

Guarino, L. 1990. "Crop collecting in the Sultanate of Oman in the context of the Arabian Peninsula ». FAO/IBPGRI Plant Genetic Resources Newsletter 77: 27-33. 
Jacomet, S. 2006. "Identification of cereal remains from archaeological sites". Unpublished manuscript.

al-Jahwari, N. S., D. Kennet, S. Priestman, and E. Sauer. 2018. «Fulayj: a Late Sasanian fort on the Arabian coast ». Antiquity 92 (363): 724-741. https://doi.org/10.15184/aqy.2018.64

Kennet, D. 1997. "Kush: a Sasanian and Islamic-period archaeological tell in Ras al-Khaimah (UAE) ». Arabian archaeology and epigraphy 8 (2): 284-302.

- - . 1998. "Evidence for 4th/5th-century Sasanian occupation at Khatt, Ras al-Khaimah ». In Arabia and its neighbours. Essays on prehistorical and historical developments presented in honour of Beatrice de Cardi, ed. by C. S. Phillips, D. T. Potts, and S. Searight, 105-16. Turnhout: Brepols.

---. 2004. Sasanian and Islamic pottery from Ras al-Khaimah (eBook version): classification, chronology and analysis of trade in the Western Indian Ocean. British Archaeological Reports 1248 (International Series)/Society for Arabian Studies Monographs, 1. Oxford: Archaeopress.

- - . 2007. "The Decline of Eastern Arabia in the Sasanian Period ". Arabian Archaeology and Epigraphy 18 (1): 86-122. https://doi.org/10.1111/j.1600-0471.2007.00274.x.

- - . 2009. "Transformations in Late Sasanian and Early Islamic Eastern Arabia: the evidence from Kush ». In L'Arabie à la veille de I'Islam. Bilan Clinique, ed. by J. Schiettecatte and C. Robin, 135-161. Orient et Méditerranée 3. Paris: De Boccard.

- - . 2012. "Archaeological History of the Northern Emirates in the Islamic Period: An Outline». In Fifty Years of Emirates Archaeology, ed. by D. T. Potts et Peter Hellyer, 188-202. Abu Dhabi, Dubaï, London: Motivate Publishing.

Kennet, D., W. M. Deadman, and N. S. Al-Jahwari. 2016. "The Rustaq-Batinah archaeological survey ". Proceedings of the Seminar for Arabian Studies 46: 155-68.

Kwarteng, A. Y., A. S. Dorvlo, and G. T. V. Kumar. 2009. "Analysis of a 27-year rainfall data (19772003) in the Sultanate of Oman ». International Journal of Climatology 29 (4): 605-617. https://doi.org/10.1002/joc.1727.

Leakey, R. R. B., and F. T. Last. 1980. "Biology and Potential of Prosopis Species in Arid Environments, with Particular Reference to P. Cineraria ». Journal of Arid Environments 3 (1): 9-24. https://doi.org/10.1016/S0140-1963(18)31672-0.

McCorriston, J., and Z. Johnson. 1998. "Agriculture and animal husbandry at Ziyadid Zabid, Yemen ». Proceedings of the Seminar for Arabian Studies 28: 175-88.

Messager, E., A. Badou, F. Fröhlich, B. Deniaux, D. Lordkipanidze, and P. Voinchet. 2010. «Fruit and seed biomineralization and its effect on preservation ». Archaeological and Anthropological Sciences 2 (1): 25-34. https://doi.org/10.1007/s12520-010-0024-1

Moez, D., 2007. Entre foi et compromis tribal: L'entrée de la région d'Oman dans l'islam. Arabian Humanities. International Journal of Archaeology and Social Sciences in the Arabian Peninsula 14: 36-62. https://doi.org/10.4000/cy.1453

Morony, M.G. 2001-02. "The Late Sasanian economic impact on the Arabian peninsula ". Nāme-ye Irān-e Bāstān (International Journal of Ancient Iranian Studies) 1(2): 25-37.

de Moulins, D., C. Phillips, and N. Durrani. 2003. "The archaeobotanical record of Yemen and the question of Afro-Asian contacts ». In Food, Fuels and Fields: Progress in African Archaeobotany, ed. by K. Neumann, A. Butler, and S. Kahlheber, 213-28. Cologne: Heinrich Barth-Institut.

Munier, P. 1973. Le palmier-dattier. Paris: G.-P. Maisonneuve et Larose.

Munt, H. 2017. "Oman and late Sasanian imperialism ». Arabian archaeology and epigraphy 28 (2): 264-284. https://doi.org/10.1111/aae.12102.

Neumann, K., W. Schoch, P. Détienne, and F.H. Schweingruber. 2001. Woods of the Sahara and the Sahel an anatomical atlas atlas d'anatomie ein anatomischer Atlas. Bern: Haupt.

Pajouh, D. P., and F.H. Schweingruber. 1993. Atlas des bois du nord de I'Iran. Téhéran: Publications de I'Université de Téhéran.

Parker, A. G., and A. S. Goudie. 2008. " Geomorphological and palaeoenvironmental investigations in the southeastern Arabian Gulf region and the implication for the archaeology of the region ». 
Geomorphology, Geoarchaeology and Geomorphology: Soils, Sediments, and Societies, 101 (3): 458-70. https://doi.org/10.1016/i.geomorph.2007.04.028.

Potts, D. T. 1990. The Arabian Gulf in Antiquity. Vol. 2. Oxford: Clarendon Press.

Priestman, S.M.N. 2019. "The archaeology of early Islam in Oman: recent discoveries from Fulayj on the Batinah » The Anglo-Omani Society Review 2019: 40-43.

al-Rawas, I. 2000. Oman in early Islamic history. Reading: Ithaca Press.

Reimer, P. J., W. EN Austin, E. Bard, A. Bayliss, P. G. Blackwell, C. Bronk Ramsey, M. Butzin, H. Cheng, R. Lawrence Edwards, M. Friedrich, et al. 2020. « The IntCal20 northern hemisphere radiocarbon age calibration curve (0-55 cal kBP) ». Radiocarbon 62 (4): 725-757.

Sanlaville, P. 2000. Le Moyen-Orient arabe: le milieu et I'homme. Collection U. Paris: Armand Colin. Schweingruber, F.H. 1990. Anatomy of European Woods. Berne: Paul Haupt.

Simpson, St J. 2019. "Nomads and Monks, Soldiers and Sailors, Farmers and Fishermen: New Archaeological Insights into Life in the Persian Gulf from Late Antiquity to the Medieval Period ». In Ex Oriente Lux. Collected Papers to Mark the 75th Anniversary of Mikhail Borisovich Piotrovsky, ed by A.A. Zolotova, 288-335. St-Petersburg: State hermitage Museum.

Smith, O., W. V. Nicholson, L. Kistler, E. Mace, A. Clapham, P. Rose, C. Stevens, R. Ware, S. Samavedam, and G. Barker. 2019. "A domestication history of dynamic adaptation and genomic deterioration in sorghum ». Nature plants 5 (4): 369.

Snape Kennedy, L. 2018. Wind, Water and Walls: Developing Geoarchaeological and Luminescence Dating Techniques for Archaeological Landscape Features. Unpublished PhD Thesis. Department of Archaeology, Durham University: Durham.

Stenhouse, J., and J. Tippayaruk. 1996. "Sorghum bicolor (L.) Moench ». In Plant Resources of SouthEast Asia $n^{\circ} 10$ : Cereals, ed. by G. Grubben and S. Partohardjono, 130-36. Bogor: Prosea Foundation.

Ṭabarī, Muḥammad ibn Ǧarīr ibn Yazīd al-. 1999. The History of al-Tabarī. Ed. by C. E. Bosworth. New York: State University of New York.

Tengberg, M. 1998. "Paléoenvironnements et économie végétale en milieu aride et semiaride: recherches archéobotaniques dans la région du Golfe arabo-persique et dans le Makran pakistanais (4ème millénaire av. notre ère e 1er millénaire de notre ère) ». Université Montpellier 2.

- - - 2005. « Les forêts de la mer. Exploitation et évolution des mangroves en Arabie orientale du Néolithique à l'époque islamique ». Paléorient 31 (1): 39-45.

- - . 2012. "Beginnings and early history of date palm garden cultivation in the Middle East ". Journal of Arid Environments, Ancient Agriculture in the Middle East, 86: 139-47. https://doi.org/10.1016/j.jaridenv.2011.11.022.

Tengberg, M., V. Dabrowski, and D. Kennet. forthcoming. "Vegetation History and Wood Exploitation at Kush (Ras al-Khaimah, UAE), 4th-17th/18th centuries AD. First Results of the Charcoal Analysis ». Arabian Archaeology and Epigraphy.

Ulbaydli, A. 1993. "The agrarian economy of Oman (132-280/749-893) in Arabic sources ». Journal of Islamic Studies 4 (1): 33-51.

Ulrich, B. 2011. "Oman and Bahrain in late antiquity: the Sasanians' Arabian periphery". Proceedings of the Seminar for Arabian Studies 41: 377-85.

Van Bergen Poole, I. 2015. "Charcoalified Wood Analysis». In Report on the Archaeological Investigation of Fulayj Fort Near Sahamon the Batinah Plain of Oman.

Van der Veen, M., and T. Lawrence. 1991. "The plant remains ». In Sobra: archaeological research at a medieval capital on the Blue Nile, ed. by D.A. Welsby and C.M. Daniels, 264-74. London: British Institute in Eastern Africa Memoirs.

Varisco, D. M. 1991. "A Royal Crop Register from Rasulid Yemen ». Journal of the Economic and Social History of the Orient 34 (1/2): 1-22. https://doi.org/10.2307/3632276.

Varisco, D. M., and 'D. Ibn Yūsuf. 1994. Medieval agriculture and Islamic science the almanac of a Yemeni sultan. Publications on the Near East, University of Washington 6. Seattle: University of Washington Press. 
Walshaw, S. C. 2010. "Converting to rice: urbanization, Islamization and crops on Pemba Island, Tanzania, ad 700-1500». World Archaeology 42 (1): 137-54. https://doi.org/10.1080/00438240903430399.

Wiersema, J. H., and J. Dahlberg. 2007. "The nomenclature of Sorghum bicolor (L.) Moench (Gramineae) ». Taxon 56 (3): 941-946.

Wilkinson, J. C. 1977. Water and tribal settlement in South-East Arabia: a study of the Afläj of Oman. Oxford: Clarendon Press.

-- . 1979. Șuhār (Sohar) in the early Islamic period: the written evidence. In South Asian Archaeology 1977, ed. by M. Taddei, 887-907. Seminario di Studi Asiatici. Naples: Instituto Universitario Orientale.

-- . 2010. Ibâdism: Origins and early development in Oman. Oxford: Oxford University Press.

Willcox, G., and M. Tengberg. 1995. "Preliminary Report on the Archaeobotanical Investigations at Tell Abraq with Sepcial Attention to Chaff Impressions in Mud-Brick ". Arabian Archaeology and Epigraphy 6 (3): 129-138. https://doi.org/10.1111/aae.1995.6.2.129.

Willcox, G. 1995. "Some plant impressions from Umm an-Nar island ». In The Island of Umm an-Nar, ed. by K. Frifelt, 2: 257-259. Aarhus: Aarhus University Press.

Winchell, F., C. J. Stevens, C. Murphy, L. Champion, and D. Q. Fuller. 2017. «Evidence for Sorghum Domestication in Fourth Millennium BC Eastern Sudan: Spikelet Morphology from Ceramic Impressions of the Butana Group ». Current Anthropology. https://doi.org/10.1086/693898.

Winchell, F., M. Brass, A. Manzo, A. Beldados, V. Perna, C. Murphy, C. Stevens, and D. Q. Fuller. 2018. " On the Origins and Dissemination of Domesticated Sorghum and Pearl Millet across Africa and into India: A View from the Butana Group of the Far Eastern Sahel ». African Archaeological Review 35 (4): 483-505. https://doi.org/10.1007/s10437-018-9314-2. 